UMR 5824

93. chemin des Mouilles 69130 Ecully - France

Maison de l'Universite, Bâtiment B 10, rue Trefilerie 42023 Saint-Etienne cedex 02 - France

http://www.gate.cnrs.fr gate@gate.cnrs.fr

\title{
Performance Feedback and Peer Effects
}

\author{
Marie Claire Villeval
}

\begin{abstract}
:
This paper reviews studies conducted in naturally-occurring work environments or in the laboratory on the impact of performance feedback provision and peer effects on individuals' performance. First, it discusses to which extent feedback on absolute performance affects individuals' effort for cognitive or motivational reasons, and how evaluations can be distorted strategically. Second, this paper highlights the positive and negative effects of feedback on relative performance and rank on individuals' productivity and persistence, but also on the occurrence of anti-social behavior. Relative feedback stimulates effort by informing on the marginal return or the marginal cost of effort, and by activating behavioral forces even in the absence of monetary incentives. These behavioral mechanisms relate to self-esteem, status concerns, competitive preferences and social learning. Relative feedback sometimes discourages or distorts effort, notably if people collude or are disappointment averse. In addition to incentive schemes and social preferences, the management of self-confidence affects the way relative feedback impacts productivity. Third, the paper addresses the question of the identification of peer effects on employees' performance, their size, their direction and their heterogeneity along the hierarchy. The mechanisms behind peer effects include conformism, social pressure, rivalry, social learning and distributional preferences, depending on the presence of payoff externalities or technological and organizational externalities..
\end{abstract}

\section{Keywords:}

Feedback, performance, peer effects

JEL codes:

C9, D91, J3, M5 


\title{
Performance Feedback and Peer Effects
}

\author{
Marie Claire VILLEVAL \\ Prepared for the Handbook of Labor, Human Resources and Population Economics \\ edited by K.F. Zimmermann, Springer
}

\begin{abstract}
This paper reviews studies conducted in naturally-occurring work environments or in the laboratory on the impact of performance feedback provision and peer effects on individuals' performance. First, it discusses to which extent feedback on absolute performance affects individuals' effort for cognitive or motivational reasons, and how evaluations can be distorted strategically. Second, this paper highlights the positive and negative effects of feedback on relative performance and rank on individuals' productivity and persistence, but also on the occurrence of anti-social behavior. Relative feedback stimulates effort by informing on the marginal return or the marginal cost of effort, and by activating behavioral forces even in the absence of monetary incentives. These behavioral mechanisms relate to self-esteem, status concerns, competitive preferences and social learning. Relative feedback sometimes discourages or distorts effort, notably if people collude or are disappointment averse. In addition to incentive schemes and social preferences, the management of self-confidence affects the way relative feedback impacts productivity. Third, the paper addresses the question of the identification of peer effects on employees' performance, their size, their direction and their heterogeneity along the hierarchy. The mechanisms behind peer effects include conformism, social pressure, rivalry, social learning and distributional preferences, depending on the presence of payoff externalities or technological and organizational externalities.
\end{abstract}

Keywords: Feedback, performance, peer effects

JEL-Code: C9, D91, J3, M5

Univ Lyon, Centre National de la Recherche Scientifique (CNRS), GATE UMR 5824, 93 Chemin des Mouilles, F-69130, Ecully, France. IZA, Bonn, Germany.villeval@gate.cnrs.fr

This work has been performed within the framework of the LABEX CORTEX (ANR-11LABX-0042) of Université de Lyon, within the program Investissements d'Avenir (ANR-11IDEX-007) operated by the French National Research Agency. 


\section{Introduction}

In order to motivate employees, companies spend considerable resources on performance evaluations, providing employees information on how well they perform in absolute or in relative terms, compared to exogenous targets or in reference to other employees. Since the eighties, almost all companies use various performance appraisal schemes of their employees (e.g., Murphy and Cleveland 1991). Technologies of monitoring have also improved considerably within companies, making the measure of performance much more precise, although subjective evaluations remain important. In parallel, the development of social networks and online platforms has favored the explosion of relative ratings in almost all domains of the society. This is expected to improve the general level of information, but this also intends to motivate people to improve their outcomes quantitatively and qualitatively.

This evolution has generated an abundant literature in psychology and management on the virtues and drawbacks of appraisal systems and on how to design the most effective feedback policies (e.g., Nadler 1979; Nordstrom, Lorenzi and Hall 1990; Kluger and Denisi 1996; London 2003; Moore and Klein 2008 for reviews). Economists have also contributed, theoretically and empirically, to the understanding of the effects of feedback policies on individuals' effort and performance. They have developed several theoretical models of optimal information provision and incentives under asymmetric information, in line with principalagent theory (e.g., Lizzeri, Meyer and Persico 2002; Gershkov and Perry 2009; Aoyagi 2010; Ederer 2010). Economists have also proposed empirical strategies to measure the effects of absolute and relative feedback on individuals' performance and identify the underlying mechanisms. This literature has shown that feedback facilitates the evaluation of the cost and return to effort but it has also revealed the crucial importance of behavioral dimensions, such as conformism, rivalry or image concerns.

Even in the absence of relative feedback from the hierarchy, employees can obtain information on their relative performance by observing their peers. Peers constitute a natural reference group to which individuals can compare their productivity. It is admitted that the first study on peer effects was conducted in psychology by Triplett (1898) who observed that cyclists were riding faster against an opponent than against the clock. This effect has been later coined as social facilitation (e.g., Zajonc 1965). Since then, various forms of peer effects have been identified in the literature in domains as diverse as crime, obesity, fertility, education and labor. If by observing others' performance individuals increase their own effort in return, such productivity spillovers can improve organizations' performance at low cost. However, it is challenging not only to identify precisely the size of such peer effects but also the mechanisms that generate them.

This paper summarizes the main insights from the economic studies conducted in the last two decades in naturally-occurring work environments or in the laboratory on the impact of the provision of performance feedback and peer effects on individuals' performance. Laboratory experiments are artificial but they present several advantages compared to quasi-experiments in the field for the identification of the underlying mechanisms. They guarantee a control of the flow and content of information, the structure of interactions, the available incentives.

First, the paper discusses to which extent feedback on absolute performance affects individuals' effort. The literature adopts either a cognitive approach or a motivational approach for evaluating these effects. It also reveals that such evaluations can be strategically distorted. Second, the paper highlights the positive and negative effects of feedback on relative performance on productivity and persistence. Relative feedback stimulates effort by informing on the marginal return or the marginal cost of effort. But it also activates behavioral forces, even in the absence of monetary incentives. These behavioral mechanisms include self-esteem, 
status concerns, competitive preferences and social learning. Relative feedback may also sometimes discourage or distort effort, notably if people collude or are disappointment averse. The impact of relative feedback depends on the incentive schemes in use and on individuals' social preferences. The behavioral and experimental literature has also revealed how the management of self-confidence affects the way relative feedback impacts productivity.

Third, the paper addresses the question of the identification of peer effects on employees' performance in the field and in the laboratory. A challenge is to disentangle the effect of the peers' contemporaneous performance on individuals' behavior from the effect of their characteristics, notably their permanent ability. The paper presents the estimated size of peer effects, their direction but also their heterogeneity along the hierarchy. Indeed, peer effects affect more low performers in some settings, and high performers in others. The mechanisms behind such peer effects include conformism, social pressure, rivalry, social learning and distributional preferences. The activation of these various mechanisms depends on the presence of payoff externalities or organizational externalities.

Synthetic tables of all studies reviewed in this paper are available in the Appendix and at: http://www.gate.cnrs.fr/survey-feedback.

\section{Feedback on absolute performance}

This section reviews the economic studies analyzing the nature and impact of feedback on workers' absolute outcome in principal-agent settings. On the agents' side, the impact of feedback on effort is studied through a cognitive or a motivational perspective. On the principals' side, studies show that feedback can be strategically manipulated.

\subsection{Cognitive and motivational perspectives}

The cognitive approach assumes that individuals have imperfect information on their ability and return to effort. If they are perfectly informed, feedback should have no impact on them. If this is not the case, feedback may affect behavior by signaling how large is the marginal return to effort. Feedback can generate both substitution and income effects. If for a given level of effort individuals learn that their performance is high (low), the substitution effect will generate an increase (decrease) of effort and a reduction (increase) of leisure, whereas the income effect will reduce (increase) effort since its return is high (low). In the literature, the empirical results are contrasted.

In a natural experiment at a UK University Bandiera, Larcinese and Rasul (2015) study whether providing feedback on performance in past semester exams influences students' score in future exams. A difference-in-difference analysis between exams and departments with different feedback regimes reveals a positive effect of feedback ( $+13 \%$ of a standard deviation). The effect is driven by students who are less informed on the academic environment, suggesting that feedback works through an information channel by giving a signal about the return to effort. A quantile regression analysis reveals that the effect is null below the $30^{\text {th }}$ quantile of the distribution of scores and it increases until the $80^{\text {th }}$ quantile. This suggests that the substitution effect prevails over the income effect. Stinebrickner and Stinebrickner (2012) also explore the informative role of feedback but they document a negative effect. Information on first semester grade point average contributes to university students' belief updating about their ability. Feedback increases dropping-out for those students who held too optimistic initial beliefs about their position in the distribution of grades and who were more certain than would suggest rational expectations.

The motivational approach examines how absolute performance feedback affects intrinsic motivation. Social psychologists have shown that feedback can improve self-esteem and 
feelings of competence, which reinforces intrinsic motivation (e.g., Arnold 1976; Burgers et al. 2015). Burgers et al. (2015) show that verbal evaluative feedback during a game increases the willingness of individuals to play again in the future. While positive feedback boosts intrinsic motivation, negative feedback may motivate individuals to try to improve to preserve their selfesteem.

Economic theoretical models of intrinsic motivation are based on the idea that people care about what others think of them (e.g., Bénabou and Tirole 2002 on intrinsic motivation, Koszegi 2006 on ego-utility, Ellingsen and Johanesson 2007 on respect, Auriol and Renault 2008 on status concerns). Individuals enjoy being thought of as good persons and they appreciate receiving approval from others. From that respect, feedback does not need to be precise to have an impact: feedback in the form of praise or through the assignment of symbolic rewards can signal the employee's value in the eyes of the principal. By signaling recognition of past effort, it expresses respect and thus, it can reinforce self-esteem and motivation. Levitt et al. (2016) find that for students who lack motivation to perform low stake tasks, non-monetary rewards attached to the improvement of own performance help children, especially the younger ones, exert more effort. Using a gift-exchange game, Eriksson and Villeval (2012) show how symbolic rewards are used by principals as a coordination device to build long-term relational contracts with more reciprocal agents, especially when the labor market is not balanced.

\subsection{Strategic distortion of feedback}

In most studies, feedback is assumed to be verifiable: when principals are better informed than the agents about their productivity, they may decide whether to release or not information but they cannot lie. However, in settings with asymmetric and unverifiable information they may bias feedback strategically (Gibbs, 1991; Prendergast, 1999), especially when the evaluation of agents' performance is subjective rather than objective.

Biasing feedback is at the principal's advantage when it brings news that motivate the agent to work harder. There is a large literature on strategic feedback in cheap talk games. In the domain of labor, Rosaz (2012) shows that principals bias feedback strategically to increase the agents' confidence. Agents trust the messages received and adjust their effort upward after receiving good news. This increases mean performance compared to truthful feedback. By contrast (but in a dynamic tournament setting), Ederer and Fehr (2007) find that biased feedback decreases performance compared to treatments with either no feedback or truthful feedback. Using a real effort weak-link game with one principal and two agents, Ertac et al. (2016) compare verifiable and unverifiable strategic feedback. Verifiable messages are more informative than unverifiable ones. However, not all principals lie and workers trust more than they should. Similar patterns are observed in a one principal-one agent setting by Mohnen and Pokerny (2006). Agents react positively to receiving good news, although less and less over time. More honest feedback is provided when the marginal return to effort is higher.

Biasing feedback may be sometimes at the agent's advantage. "Leniency bias" appears when supervisors report higher performance ratings than the actual employee's performance (Prendergast 1999). This occurs when raters suffer from bringing bad news to employees by fear of confrontation, because of inequality aversion, empathy or efficiency concerns. "Centrality bias" is the tendency to compress performance ratings leading to less variance in ratings than in performance. This occurs when the cost of gathering information on employees' effort is high or if raters fear criticism.

In a real-effort experiment, Rosaz and Villeval (2012) find that one third of raters misreport their agent's performance, mainly for monetary reasons. A majority of them inflate their agent's performance when this increases both the agent's payoffs and theirs; misreports that increase the rater's payoff at the expense of the agent represent a third of the lies. But the literature has 
also identified non-monetary motives. Using data from a financial service provider, Bol (2011) finds evidence of both centrality and leniency biases, the latter being more pronounced for employees whose objective performance is below average. This is correlated with the strength of the employer-employee relationship. Breuer, Nieken and Sliwka (2013) also find evidence of upward biases when social ties between supervisors and appraised employees at a call center are closer, notably when team size is smaller or social ties older.

One reason behind leniency is that a fair but negative subjective evaluation may trigger retaliation from employees who receive an image-threatening low rating, even when rating has no impact on payoffs (Sebald and Waltz 2014). Self-confidence plays a role in this process, regardless of the monetary incentives at stake. In a principal-agent setting with imperfect information on both sides, Bellemare and Sebald (2019) find that overconfident employees whose rating lies below their own evaluation engage in costly punishment, while they do not reward ratings that lie above their own. The opposite is found for underconfident subjects. Such reciprocity may encourage leniency.

How do such biases impact future performance? Agency theory predicts that they weaken the incentive to perform. Bol (2011) shows that centrality bias negatively impacts performance, consistently with the theory. By contrast, leniency bias affects it positively, which could be explained by an increased intrinsic motivation resulting from perceived fairness. Contrary to Bol (2011), Marchegiani, Reggiani and Rizzolli (2016) find in a real effort laboratory experiment that leniency is detrimental to performance. But rewarding undeserving agents has a less detrimental effect than failing to reward deserving agents (the "severity bias"), contrary to what agency theory predicts.

These biases have led some companies to introduce forced rating distribution with limited number of positions in each rating. The effect of such scheme on productivity has been studied by Berger, Harbring and Sliwka (2013) in a real-effort experiment. In comparison with free appraisal, forced distribution reduces leniency and increases productivity by 6 to $12 \%$. The effect is, however, much lower when workers are able to sabotage each other. Forced distribution schemes have also raised concerns in terms of fairness and complexity (Schleicher, Bull and Green 2009).

\section{Feedback on relative performance and rank incentives}

The economic literature on the impact of relative performance feedback on future effort is abundant but provides mixed results, like the literature in social psychology (about one third of the studies surveyed in the meta-analysis of Kluger and Denisi 1996 have identified negative effects). Several mechanisms motivate these contrasted findings. This section first reviews the evidence of positive effects of relative feedback on effort. These effects derive from improved self-esteem and competitive preferences, rather than from more accurate self-perception and social learning. Next, this section reviews the negative effects of relative feedback that may result from discouragement, stress, anti-social behavior and effort distortion. Finally, the section reviews the studies analyzing how feedback interacts with the strategies developed by individuals to manage their confidence, notably through biased beliefs. Each subsection presents first studies conducted in natural settings and next, laboratory experiments.

\subsection{The positive effects of relative feedback: Self-perception, competitive preferences and social learning}

Relative performance feedback may impact effort for both monetary and non-monetary reasons. Monetary mechanisms may be at play when feedback helps agents rewarded according to their relative performance to adjust effort in order to succeed. Non-monetary mechanisms may have 
an influence even when incentives are not attached to output. The very nature of the mechanism can be identified by examining which category of agent is more impacted.

An explanation in terms of beliefs and learning anticipates asymmetric and opposite effects of relative feedback on effort depending on one's rank: lower performers may get discouraged and reduce effort while top performers may increase it. By providing a more accurate information on their position in the score distribution, relative feedback can improve individuals' selfconfidence, help them update their beliefs about the marginal return of effort and thus provide the optimal level of effort.

An explanation in terms of social norms also predicts opposite effects of feedback depending on relative ability, but in the opposite direction: low performers should increase effort while top performers should reduce it to conform to the norm. An explanation in terms of social learning should concentrate the effect of feedback on the relatively low performers. Individuals who learn they are below the average may try to learn from those who are ranked higher.

Finally, an explanation in terms of competitive preferences and status concern anticipates a similar effect of feedback along the performance distribution. Learning that one is better than the others generates pride, while the opposite generates shame (e.g., Smith 2000). The role of social comparisons has been documented decades ago by social psychologists (e.g., Festinger 1954; Locke and Latham 1990; Pearce and Lyman 1986) and more recently by economists (for theoretical models on status concerns see, e.g., Moldovanu, Sela and Shi 2008, Auriol and Renault 2008, Besley and Ghatak 2008).

\subsubsection{Field evidence}

This subsection reviews successively studies conducted in primary, secondary and college education and finally, at the workplace.

\section{Feedback at school}

In schools, positive effects of relative feedback are found at the intensive and at the extensive margins. For example, Celik Katreniak (2018) find an overall positive effect in Ugandan schools, especially when within-class feedback and financial rewards are combined, but at the cost of increased stress. Andrabi, Das and Ijaz Khwaja (2017) have conducted a Randomized Controlled Trial (RCT hereafter) in Pakistani schools. Parents and schools received report cards with the children's test scores and quintile rank, and the mean score of all schools in the village. The positive effect of feedback on performance results from a better organization of the educational market and the mobility permitted by such information provision.

Positive effects are found even when children are rewarded for their absolute performance, but there is no consensus on which types of students benefit the most from social information.

Some studies find that most skill categories benefit from feedback. Using a natural experiment in a high school, Azmat and Iriberri (2010) show that when students learn about their performance compared to the class average, this increases grades by $5 \%$ on average. This is observed both when news is good and when it is bad, especially at the tails. This suggests that it is driven by competitive preferences more than by the updating of self-perception. Comparing various non-monetary incentives on $6^{\text {th }}$ graders, Jalava, Joensen and Pellas (2015) find that rank-based grading and symbolic awards increase the effort of the high achievers and the two middle quartiles benefit the most from these non-monetary incentives. No significant effect of any intervention is detected for the low achievers. 
Other studies find that the effects of feedback on future performance are asymmetric but, depending on the study, they concentrate either on low or high achievers. This suggests instead an explanation in terms of confidence and information processing.

On the one hand, Fischer and Wagner (2018) identify a positive effect of rank feedback that is stronger for students who receive bad news. The timing of feedback matters: rank feedback based either on performance in the last exam or on the progress between the last two exams improves the final score when received a few days before the final exam (but decreases it when feedback is received immediately before). Bad news has an immediate negative emotional effect but it conveys the necessity to work harder to catch up, provided there is enough time. Focusing on teachers in a Dutch school, Buurman et al. (2020) find that receiving feedback from students has no effect, on average, on teachers' score measured a year later. However, feedback stimulates the effort of female teachers who learn that their assessment is lower than their own perception or than the evaluation of their colleagues.

On the other hand, some studies show that only good news increase effort. Goulas and Megalokonomou (2018) exploit a natural experiment in Greece where social information includes rank in two reference groups (the school and the country). They measure positive short term and long term effects of public rank feedback on high achieving students but negative effects on low achieving students, with stronger effects for females on both sides of the distribution. Similarly, in a field experiment with teachers in secondary schools in Romania, Cotofan (2019) finds that receiving an unexpected public praise based on relative performance boosts confidence and increases teachers' performance persistently, whereas not being praised signals lower performance and discourages effort. Repeated/expected praise has no further effect. These results support an interpretation in terms of learning and belief updating.

\section{Feedback in higher education}

Positive effects have been found also in higher education. Providing feedback on relative performance at a midterm exam in a Japanese university where final grading depends on both the raw score and the relative position in the distribution (a kind of ranking tournament) improves outcomes in final exams on average (Kajitani, Morimoto and Suzuki 2017). This is driven by the improvement of the low-performing students. Brade, Himmler and Jäckle (2018) inform first-year students of a German university on their relative course credits compared to the median and to the student in the $80^{\text {th }}$ percentile. Feedback has a positive effect on grades only when associated with a positive normative message for students to perform better. The effect is driven by the students who underestimated their relative performance. Updating of beliefs is asymmetric and plays a major role when social norms are made salient.

Rank incentives provide more precise information on relative performance and activate competitive preferences. In a Vietnamese university, Tran and Zeckhauser (2012) observe a large increase in score in the final TOEIC test when students that enrolled in an English course received information on their rank, regardless of whether information is made public or not. This result is stronger for the best students who are motivated by rank but lower score students work also harder to improve. Using a one-year RCT in which students receive real time, continuous and private relative feedback in a semester-long assignment, Dobrescu et al. (2019) identify precisely strong and lasting rank incentives. The advantage of using online tasks with no bearing on students' grades is that performance has no signaling value, by contrast with previous studies. A positive spillover effect is found on the mean grade in all course exams across all quantiles of students. The effectiveness of rank feedback seems to derive from social learning: feedback questions students on whether they are using the most effective method to achieve their assignment; informed students post more messages in the discussion boards. Students learn to develop better studying habits and more interactions with peers. 


\section{Feedback at the workplace}

Few studies have been conducted within companies. Most studies conducted in a working environment confirm the positive effects of feedback found in the context of education across a variety of incentive schemes. Status concerns and social image play a major role.

In some companies, relative feedback takes the form of public recognition. In a controlled field experiment in which workers are recruited for a two-hour data-entry job for which they are paid a flat wage, Kosfeld and Neckerman (2011) show that promising a symbolic award to the best two performers increases workers' performance by $12 \%$ on average, with a stronger effect on more productive workers. This supports a model in which utility increases with status recognition. In a similar controlled field experiment, Bradler et al. (2016) use symbolic rewards (a thank-you card) but here, awards are unannounced to the workers. Performance increases in reaction to public praise when all employees are praised, but it is stronger when only the best three performers receive recognition. In contrast to Kosfeld and Neckerman (2011), this effect is driven more by the nonrecipients. This can be explained both by lower achievers' preference for conformity and best achievers' reciprocity.

Status concerns and competitiveness have more complex effects in high-risk work environments. Using data from German fighter pilots during World War II, Ager, Bursztyn and Voth (2016) identify the spillover effects recognition of a pilot exert on the motivation and risk taking of peers. After a given pilot's accomplishment received praise in the armed force bulletin, the most able pilots tried harder, succeeded more but died more because of higher risk taking; average pilots' performance did not increase but they also took more risk and the death toll increased. Relative feedback associated with non-monetary incentives and closer social distance increases effort in the presence of status competitiveness but has mixed effects on efficiency.

Relative feedback may also increase performance when associated with individual or team performance pay. In a quasi-experimental study in a German wholesale and retail company, Blanes i Vidal and Nossol (2011) measure the productivity of employees who are paid a piece rate and receive a monthly relative feedback. Such feedback has a strong and long-lasting impact on productivity ( $6.8 \%$ on average) that is attributed to an increased concern for relative position. These findings replicate under team incentives. For example, Delfgaauw et al. (2013) study a retail chain in the Netherlands where employees were paid according to the performance of their team and stores had to compete for six weeks. The weekly feedback on the store's rank in terms of sales growth leads to a 5\% increased sales growth. The effect is conditional on the store's manager being of the same gender as a high share of the employees, but not on the presence of a monetary reward to winning the tournament. Managers may be better at communicating the firm policy to employees of the same gender or at creating a team cohesion and emulation with same gender employees.

These results are particularly interesting since informational interventions cost almost nothing to companies. They generate the incentive effects of tournaments without monetary prizes. When monetary incentives are introduced in tournament settings, relative feedback increases effort further, although with a high degree of heterogeneity. Analyzing a dynamic contest among retailers of a commodities manufacturer, Casas-Arce and Martinez-Jerez (2009) show by means of difference-in-difference regressions that the average output of the participants increases more than the output of the non-participants. In the contest, retailers who learn they are lagging behind increase their effort to catch up, except when the gap with the leader gets too large, while frontrunners decrease effort when they become aware of their position. Using data from multi-stage weight-lifting competitions where athletes have to announce publicly the weight they intend to lift, Genakos and Pagliero (2012) also identify an inverted U-shaped relationship between interim rank and subsequent risk-taking, with competitors lagging behind 
more likely to increase risk-taking for catching up compared to those who lead. This behavior is consistent with information processing and competitiveness.

Besides variations in incentive schemes, the impact of relative feedback also depends on its publicity. Making employees' performance public can be seen as a monitoring device. Lount and Wilk (2014) show that posting the individual performance of team members in a call center increases effort compared to when employees work alone. It eliminates the social loafing that is observed when team work is introduced and performance is not posted. This is attributed to social comparisons.

\subsubsection{Laboratory experiments}

These positive results replicate in laboratory experiments where subjects are usually not familiar with the task and do not know those they are compared with, which makes relative feedback particularly informative. The comparison between treatments in which feedback and incentive schemes are manipulated together in a controlled environment help identify the mechanisms behind the effectiveness of such feedback.

\section{Flat wage schemes: The impact of ego-utility, concerns for rank and social comparisons}

Feedback on performance rank has been found to increase productivity in contexts where earnings are independent of performance. Self-esteem or ego utility play an important role. Kuhnen and Tymula (2012) show that under a flat wage scheme people work harder when they know that they may learn their rank. There is also a ratcheting effect of feedback on productivity: ex post, those at the top of the hierarchy fight for dominance to keep their rank, while the positive effect of feedback is less strong for those who learn they are ranked lower than expected. Since feedback remains private, this effect cannot be driven by social image.

Gill et al. (2018) also consider a flat wage environment where students perform two tasks. Instead of looking at the gap between expectations and actual rank, they study the causal effect of a precise rank in the distribution of performance on subsequent effort provision. The rank response function is U-shaped: relative to the average effort in the group, being ranked first increases performance in the next round by $21 \%$ ("first-place loving") and being ranked last increases it by $13 \%$ ("last place loathing"). By contrast, learning that one is ranked in the middle reduces effort by more than $10 \%$. Since ranking does not impact earnings or prospects, this reveals a pure taste for rank driven by both the pride of winning and aversion for the last rank.

In Gill et al. (2018) the effect of learning one's rank is similar when information is displayed publicly or privately. Cadsby et al. (2019) also find no difference between private and public display of rank feedback both in a standard student-subject pool and in a sample of employees from manufacturing companies in China (similar conclusions arise in Gerhards and Siemer 2012). This differs from other studies showing that the motivational effect of feedback increases when information is made public because of social comparisons, peer monitoring or status concerns (e.g., Mas and Moretti 2009; Tajkov 2013). The precision of feedback is another dimension that influences the impact of rank feedback. In a flat pay setting Drouvelis and Paiardini (2019) observe that only a precise rank feedback increases productivity in all ranks, whereas a vague feedback only increases the productivity of those who receive a poor evaluation compared to no feedback.

\section{Performance pay schemes: The impact of status concerns and regret avoidance}

When there is a pecuniary return to effort, relative feedback may still activate status concerns but it takes a strategic dimension that depends on the structure of incentives. In Azmat and Iriberri (2016), performance increases by $17 \%$ on average when relative feedback is provided under piece rate but not under flat rate, regardless of whether the subject performs above or 
below the average. By contrast, the effects on satisfaction are divergent depending on receiving positive or negative feedback. In Hannan, Krishnan and Newman (2008) the impact of feedback depends on the precision of information: it is positive when subjects are paid a piece rate but null when people are paid a flat wage, and feedback must be precise to be effective. However, Cadsby et al. (2019) note that it is impossible under a piece-rate scheme to disentangle the effect of learning one's rank from the effect of learning one's relative payoff. They find that the impact of feedback is reinforced when ranking is public and compensation is rank-based compared to private feedback and a fixed pay setting. However, they cannot replicate this finding with factory employees (like So et al. 2017 who use a standard student subject-pool).

In contests where effort influences only the probability of winning, the marginal effect of effort on this probability is constant. In equilibrium, feedback should thus have no effect on purely selfish agents. However, individuals react to feedback. Fallucchi, Renner and Sefton (2013) show that in rent-seeking contests individuals best respond to the information received on the rival's decision or imitate successful competitors. In share contests where contestants receive a share of the rent corresponding to their share of expenditures, feedback increases expenditures and favors imitation. But in lottery contests where the winner gets the whole rent with a probability that depends on his or her share of expenditures, feedback reduces effort because best response learning moderates the effect of imitation.

Differently from this study, the ex post feedback introduced in a lottery contest by Mago, Samek and Sheremata (2016) does not affect the overall future effort but it decreases its heterogeneity because of opposite effects. A pure non-monetary utility of winning is rejected for an explanation in terms of relative payoff maximization and regret: winners would regret paying too much in the lottery while losers would regret missing an opportunity. In a two-stage tournament with interim information Ludwig and Lünser (2012) also find behind the absence of an overall effect that feedback increases the effort of those who lag behind halfway and decreases the effort of the frontrunners. In the second stage, the difference in effort between frontrunners and underdogs increases in the first-stage effort gap, which is consistent with the results of Casas-Arce and Martinez-Jerez (2009) in a field setting. The interpretation is that agents concerned about their relative standing adjust effort to the information received to prevent negative emotions. In particular, the marginal cost of effort increases for statusconcerned players who learn they are lagging behind.

Using a real effort maze-solving task, Freeman and Gelber (2010) show that providing information about the competitors' ability in a preliminary but independent stage increases further the difference in mean performance in subsequent tournaments with multiple prizes, compared to tournaments with a single prize. Full information also increases performance when all contestants receive the same prize. By contrast, Newman and Tafkov (2014) find that when only top performers are rewarded in tournaments, relative feedback has a negative overall impact. However, when the prize structure both rewards the best performers and sanctions the bottom performers, the effect of relative feedback becomes positive on all contestants since it informs everyone that the marginal return of additional effort is positive, in terms of increased probability either of winning the prize or avoiding the sanction.

Finally, considering the external margin of effort, Eriksson, Poulsen and Villeval (2009) observed that in tournaments, underdogs who receive continuous or interim feedback almost never quit the competition even when they are lagging behind and it is clear that they have no chance to win the tournament; also front runners are still working hard although it is clear that they cannot lose their first rank.

Overall, many field and lab studies identify positive effects of feedback on relative performance on future effort. These effects exist even in the presence of only non-monetary incentives but 
they seem larger when combined with competitive or non-competitive performance pay schemes. In most settings -but not all- these effects are heterogeneous, depending on the individuals' relative ability. The main drivers of such positive effects are social comparisons, competitive preferences, and regret avoidance.

\subsection{The negative effects of relative feedback: Collusion, discouragement and anti-sociality}

Relative performance feedback and rank incentives may also have heterogeneous negative effects on performance. Different mechanisms are at work, including belief management and competitive preferences, social status concerns, discouragement or the internalization of negative externalities of ranking.

\subsubsection{Field evidence}

Field studies have revealed negative effects of relative performance feedback either at the top or at the bottom of the hierarchy.

\section{Top performers: Competitive preferences, choking under pressure and collusion}

Relative feedback has sometimes a negative effect on top performers' effort. The discrepancy between beliefs and one's actual position in the distribution of performance plays a complex role. Indeed, a negative effect of relative feedback has been found both for people who underestimate their relative performance and for those who overestimate it.

Individuals may adjust their effort downward if they realize that their relative performance is higher than expected, i.e., if the income effect dominates. In an RCT Azmat et al. (2019) gave college students feedback on their decile rank in the grade distribution every six months during three years. This feedback reduces performance in the short-run, especially for students who initially underestimated their position in the grade distribution. Differences in competitive preferences could explain that some categories of individuals have opposite reactions to feedback. This is illustrated by an RCT in which university students were informed on their exact placement among their classmates on a daily basis (Cabrera and Cid 2017). Feedback has a negative effect on females' satisfaction and academic outcomes, regardless of their relative position. This might result from a higher cost of effort or lower competitiveness.

However, even people with competitive preferences may adjust their performance downward after receiving feedback. In Genakos and Pagliero (2012), athletes who learn that their interim rank in weight-lifting tournaments is closer to the top tend to take less risk. Interestingly, their subsequent performance also decreases, which might result from choking under pressure.

Collusion and conformity to social norms may also lead to a negative reaction of the high performers, especially if social ties among co-workers are sufficiently developed. In this context, workers may try to internalize the negative externalities created by their positive ranking on their co-workers. Two studies illustrate this mechanism.

Blader, Gartenberg and Prat (2019) conduct a field experiment in a US transport company that introduced an electronic on-board recorder technology. This technology can inform drivers on their performance, by posting individual statistics publicly, anonymously or not. Although there is no link between performance and payment schemes, relative feedback either increases or decreases drivers' fuel efficiency, depending on the nature of the relational contract with the company. Relative feedback has a positive impact on fuel efficiency $(+4.5 \%)$ in the sites where an individualistic culture prevails, whereas its impact is negative $(-10.7 \%)$ in the sites where teamwork and a cooperation-based relational contract have been introduced. This negative effect is attributed to the tension between the competitiveness encouraged by the use of relative feedback and the cooperativeness encouraged by the new managerial policy. A more 
cooperative orientation leads better performers to reduce their performance to avoid harming lower performers. Based on a ten-month intervention in a Bangladeshi sweater factory, Ashraf (2018) also finds that workers who are ranked higher than their friends subsequently decrease their performance when feedback is reported publicly. Such conformity effect may result from the fear of social punishment.

\section{Low performers: Discouragement and status concerns}

Feedback may also have a negative effect at the other tail of the distribution: low achievers and individuals who overestimate their ability. We have already mentioned the study of Goulas and Megalokonomou (2018) in the domain of education. The mechanism driving this result may be information updating about one's ability but also self-image and a concern for status. When individuals learn that they are placed lower than they expected in a performance ranking, they may feel demoralized or ashamed. This effect has been evidenced for commission-paid furniture salespeople by Barankay (2012) in a field experiment in which feedback on rank was no longer provided to a fraction of the employees. Rank feedback reduces the volume sold by $20 \%$ and this effect is driven by males.

Social status concerns may also generate a backlash of relative feedback through the endogenous selection of co-workers in teamwork settings. When workers who are paid a piece rate based on aggregate productivity of each team form a team, they select their co-workers based on their ability but also on social ties and friendship. Using data from a fruit picking farm, Bandiera, Barankay and Rasul (2013) show that the introduction of rank incentives changes the way people select their team members. When teams' productivity is publicly posted, people match mainly by ability because of social status concerns. This results in a $14 \%$ decrease of productivity and an increased variance in productivity across teams. Quantile regressions show that this is driven by the low ability teams in which the share of team members connected by social ties has decreased. Free riding can no longer be mitigated by these ties through mutual monitoring.

Discouragement effects of rank feedback on low performers are also observed at the extensive margin. Individuals may quit or not return to work after receiving feedback. Illustrating the first phenomenon, Fershtman and Gneezy (2011) measured performance in 60-meter running races between $10^{\text {th }}$ graders in Israeli schools, while manipulating incentives and feedback. While larger stakes increase effort, some quitting is observed but only when children run side-by-side and can thus observe continuously the gap in performance with the competitor. Illustrating the second phenomenon, Barankay (2011) recruited workers on MTurk for analyzing images and found that those who received rank feedback are $30 \%$ less likely to return to work compared to those who were not informed on their rank, although the piece-rate payment is not affected by performance rank. At the intensive margin, when information was provided after they returned, productivity decreases by $22 \%$ in the sample of informed workers. No evidence of heterogeneity in terms of expectations is found.

A negative effect on the extensive margin has also been observed by Haenni (2019) among amateur tennis players. Participation in such competitions is voluntary and opponents are randomly assigned, which serves as an instrument in the IV strategy and helps identify the causal effect of ranking difference between the contestants, using regression discontinuity. After a competition, losers wait $10 \%$ longer before enrolling again, especially when losing against a relatively weaker competitor in the national ranking. While Bayesian players should not update their beliefs after losing against someone relatively close in the ranking, this discontinuity after a defeat against a weaker opponent suggests that players lose more utility when the reference point -their current ranking- is violated by the defeat. Such reduced 
reference dependent utility generates discouragement and lowers aspirations and the motivation to compete in the future.

Note that the simple willingness to avoid discouragement can produce a similar effect. This is how one can interpret the results of a field experiment conducted by Ashraf, Bandiera and Lee (2014) in Zambia during a training program of health workers. According to the treatment, trainees could receive only feedback on their absolute score, or also feedback on their rank in the class, or on top of that, the names of the best performers. In some conditions, information on the rank could be complemented by awards that were assigned, either privately or publicly, to the best performers and to those that improved the most. The results show that feedback on relative performance, whether private or public, reduces test scores, an effect that is outweighed by the introduction of symbolic awards. Interestingly, this negative effect that is stronger on the left of the productivity distribution, occurs before trainees receive the rank information. This suggests that some individuals are willing to reduce their effort to avoid receiving bad news on their ability, i.e., to reduce the informativeness of the signal. This behavior would be consistent with other strategies used by individuals to avoid or forget relevant information about the self for affective or strategic reasons (Benabou and Tirole 2002).

By means of an RCT in German high schools Hermes et al. (2019) demonstrate that the negative effect of relative feedback on the low-achievers can be avoided if relative feedback is based on score improvement rather than absolute performance. This result is based on the higher performance achieved in a group that receives continuous ranking feedback in a mathematics program compared to a control group that receives feedback on individual performance. In both cases, feedback is based on the scoring of individual performance improvements. The combination of social information and feedback on improvement has a boosting effect on the motivation of initially low achievers (especially females) without any detrimental effect on high achievers. Higher self-efficacy is achieved, however, at the cost of higher reported stress.

\subsubsection{Laboratory experiments}

Laboratory experiments show that discouragement and disappointment aversion are important mechanisms behind the negative effects of relative feedback on effort. They identify additional detrimental effects of relative feedback in terms of decreased quality of work, anti-social behavior and effort distortion. These effects may depend on incentive schemes and organization performance technologies.

\section{Discouragement and disappointment aversion}

Several experiments identify discouragement effects when feedback reduces or eliminates strategic uncertainty. In particular, effort may be affected negatively when individuals receive information during competition, when such information is provided either in the mid-term of a dynamic tournament or sequentially after the competitor has chosen his or her own level of effort. In Gürtler and Harbring (2010), less productive agents exert less effort after receiving interim information revealing that the ability gap with the competitor is large. Thus, principals who cannot commit ex ante to a revelation policy are less likely to release information when this gap is large. However, non-revelation is informative and also decreases workers' effort.

Disappointment aversion can explain that in tournaments with sequential moves individuals may decrease effort in response to the competitor's relatively high performance. Using a novel "slider task" Gill and Prowse (2012) design a tournament in which the winning probability depends on the difference in the agents' effort levels. Despite the fact that the marginal effect of an extra effort on the winning probability does not depend on the first mover's effort, second movers decrease effort after learning that their competitor worked hard. Such discouragement can be generated by disappointment aversion, i.e., loss aversion around an endogenous 
reference point based on expectations and the instantaneous adjustment of this reference point to the effort level of the player and the competitor. The authors reject alternative explanations such as probability weighting, regret (subjects cannot observe any counterfactual), choking under pressure (marginal incentives do not depend on the first movers' effort), or collusion (pairs are rematched after each round).

Reduced quality of work

Relative feedback may not only or not necessarily affect the quantity of effort, but it may also alter its quality. In a real-effort experiment, Eriksson, Poulsen and Villeval (2009) investigate how often an organization should provide relative feedback to its agents who are incentivized either by a piece rate or a tournament. Subjects receive either no feedback, continuous feedback or half-way feedback about their relative performance in a pair. The provision of relative feedback never changes the average performance but it increases significantly the number of mistakes of the low performers under both incentive schemes, suggesting the presence of negative quality peer effects. A possible explanation is that social comparisons increase pressure and thus, the stress experienced by workers with negative consequences on the quality of their effort. In a game involving production decisions, Hannan, Krishnan and Newman (2008) find a decreased mean performance in tournaments when feedback is precise, while the opposite is observed when compensation is based on individual performance. The reduced performance of the low achievers is attributed to feedback since performance is higher in tournaments without feedback when compared to an individual compensation scheme. This does not result from a reduction in effort levels but from the use of less effective strategies. However, these effects may depend on the context, as for example Katreniakova (2014) does not find evidence of increased stress due to relative feedback in a school setting.

\section{Anti-social behavior}

Relative feedback may generate anti-social behavior if employees are able to sabotage their peers or cheat on their own performance. In competitive settings such as tournaments, sabotage is not rare and its likelihood increases in the spread between the winner and loser prizes. Cheating on one's own performance is also more likely when subjects are informed on their relative ability in a pre-tournament task (Freeman and Gelber 2010). Multiple motivations can play in competitive settings: greed, value signaling, joy of winning and preferences for rank.

But relative feedback can trigger anti-social behavior even without any expectation of monetary return. Experimental studies in management have documented counterproductive behavior that take the form of reduced willingness to share knowledge or even sharing fake information with co-workers under individual performance pay (e.g., Berger, Fiolleau and MacTavish 2019). The real effort experiment of Charness, Masclet and Villeval (2014) shows evidence of both sabotage and doping under a flat payment scheme. A minority of subjects are willing to sacrifice payoffs to avoid the last rank or to reach the first one in triads. This behavior is often associated with higher real performance, revealing status seeking and competitive preferences.

Such effects of feedback on morale are not systematic. For example, Heursen (2019) find no spillover effect of public or private rank feedback on performance in a quiz on the willingness to help group members in a subsequent task. This is obtained regardless of the payment scheme in the main task and despite an increased competitive mindset and perceived social distance between group members due to rank feedback.

\section{Effort distortion}

The impact of relative feedback may depend on organizational modes. It differs between singletasking and multi-tasking work environments when employees have some discretion in the 
organization of their work, and between organizations whose results are tied either to the performance of each employee, the performance of the best achievers or that of the less able.

In a multi-tasking environment, relative feedback can distort the allocation of effort across tasks in a way that generates inefficiencies. Individuals encouraged to compare their performance may increase effort in activities where they can outperform others, which improves their selfesteem, and decrease effort in those where they are less able. Evidence of such distortion in terms of the time allocated to two problem-solving tasks with negative marginal return to effort has been provided by Hannan et al. (2013). The distortion is larger when subjects learn the rank of each group member in each task and not only their own. It cancels out the beneficial effect of feedback on motivation. This is consistent with the self-affirmation theory in psychology: individuals react to a threat to self-image in one domain by increasing effort in another domain.

Ertac, Gümren and Koçkesen (2019) show that the impact of feedback depends on organization performance technologies. Two-agent teams are characterized by homogeneous or heterogeneous ability levels. Principals have private information on agents' ability and decide whether releasing or withholding this information. As predicted, a fully revealing strategy is more effective if team performance is determined by the top performer (best-shot game), except if the team is composed of low performers. By contrast, a withholding strategy is better if team performance is determined by the bottom performer (weak-link game), except if the team is composed of high ability members. Revealing heterogeneous abilities lowers the average effort.

\subsection{Relative feedback and confidence management}

The management of self-confidence is crucial in many aspects of life, for both affective reasons (ego is a source of utility, Kószegi 2006) and strategic reasons (it helps motivate the future self and it is easier to convince others of one's value if one is convinced oneself, Benabou and Tirole 2002). Three main categories of self-deceptive strategies relative to performance feedback are used by people to maintain a positive self-view: people interpret the information they receive self-servingly and they update beliefs asymmetrically; they forget self-view-threatening information; they actively avoid receiving feedback. These strategies explain that overconfidence persists despite the provision of relative performance feedback.

\subsubsection{Motivated information processing}

Feedback help people update their beliefs about their and others' relative ability, which should improve their future decisions. For example, Wozniak, Harbaugh and Mayr (2014) show that the gender gap in competitiveness disappears once players receive relative performance feedback, as high-ability females compete more and low-ability males compete less. However, many people deviate from Bayesian updating when information is about ego-relevant variables. People update their beliefs insufficiently and asymmetrically because of biases such as conservatism (updating is partial), self-serving attribution (they weigh more the signals that increase their self-interest) or confirmation (inconvenient signals are ignored).

Using an IQ test with a piece rate payment scheme and eliciting subjects' beliefs on scoring in the top half with a crossover mechanism, Möbius et al. (2011) find that individuals update their beliefs conservatively after receiving a noisy binary signal (35\% as much as a Bayesian should do) (Möbius et al. 2007 show that this is especially the case for females). They also update beliefs asymmetrically: they overweight positive signals relatively to negative ones and they update upward when receiving non-informative feedback. Informing subjects on their precise rank in a beauty rating and an IQ test, Eil and Rao (2011) also observe asymmetric updating: people update in a Bayesian way after receiving good news but they discount bad news. 
Ertac (2011) considers both precise (being on the top of the distribution or not, on the bottom or not) and ambiguous signals. Using a quadratic scoring rule to elicit beliefs like Eil and Rao (2011), she shows that individuals react more to performance feedback than to equivalent but ego-irrelevant information. However, while self-confident people update self-servingly and too optimistically, the others overweight negative feedback: when informed that they are not in the top, they report a too high probability of being in the bottom. Such pessimistic updating differs from the previous studies, possibly because performing relatively poorly in algebraic and verbal tasks is less image-threatening than being poorly ranked in terms of intelligence or beauty. Using various cognitive tasks, Buser, Gerhards and van der Weele (2018) also find evidence of conservatism bias but they do not observe asymmetric updating. They suggest that the responsiveness to feedback constitutes a personal trait of individuals.

Even if repeated relative feedback helps people reduce their optimism bias in a given activity, it does not necessarily debias them in other contexts (e.g., Rose and Windschitl 2008). Relative feedback in one task may even increase confidence biases in other activities. There is some evidence both from the field (Banerjee, Data Gupta and Villeval 2018) and the lab (Huang and Murad 2018) that being informed that one is better than the rivals in one task inflates beliefs on one's ability to succeed when competing in another, unrelated, activity. By contrast, receiving bad news in the prior activity does not affect beliefs about the ability to succeed in the subsequent task. Such bias develops through both motivated beliefs and tastes and may lead to suboptimal future decisions.

\subsubsection{Selective memory of feedback information}

A second strategy to manage self-confidence involves selective memory. The distortion of memory includes both selective recalls and biased memory (defined by the direction and magnitude of the memory errors). Chew, Huang and Zhao (2019) extend the model of Benabou and Tirole (2002) to include delusion. They give an immediate feedback to subjects on the correctness of their answers in an IQ test, and they invite them several months later to recall for each item (and for items they did not see earlier) whether they gave a correct answer or not. They find evidence of positive delusion, confabulation and amnesia. People are more likely to recall desirable rather than undesirable information about themselves and they create positive false memories that inflate their self-view and confidence in the future self.

While Chew et al. (2019) consider absolute performance, Zimmermann (2019) analyzes the evolution of beliefs after individuals receive a noisy feedback on their relative performance in an IQ test. Three subjects are randomly selected in a group of ten and subjects are informed on whether their rank is higher or lower compared to each of them. Individuals do update their beliefs about their rank in the group of ten immediately after receiving the feedback, regardless of its valence. However, one month later, the beliefs of those who received initially a positive feedback remain updated upward, but those who received a negative feedback return to their initial level of confidence: individuals suppress bad news. In sales tournaments, Huffman, Raymond and Shvets (2019) find a correlation between managers' overconfidence about the ability to succeed in a future task and exaggerated memory about their past success. Distortion of memory can be strategic to motivate beliefs for future action.

\subsubsection{Feedback avoidance}

While there is some evidence of performance curiosity (e.g., Alos-Ferrer, Segarra and Ritschel 2018), a third strategy to manage self-confidence is relative feedback avoidance. Möbius et al. (2010) show that about $10 \%$ of their subjects are willing to bid for avoiding a noiseless information about their performance. Feedback aversion is more frequent among less confident individuals. In Eil and Rao (2011), subjects with high expectations are willing to pay to learn 
their exact rank, whereas those with low expectations are willing to be paid to avoid receiving such information. In a lab-in-the-field experiment with trainee truck drivers, Burks et al. (2013) show that more confident drivers are more likely to search for additional information on their relative performance. Overconfidence is motivated more by the willingness to impress others than by self-image concerns. This favors a social signaling explanation (Benabou and Tirole 2002) against an explanation in terms of ego-utility (Koszegi 2006), since the latter would predict that more confident people are more likely to avoid information to preserve self-image.

To sum up, most people care about the content of absolute and relative performance feedback. Whether the effect of such feedback on effort is positive or negative depends both on rational and behavioral dimensions, including incentive schemes and work organization, expectations and belief updating biases, individual and social preferences such as competitiveness, status seeking and self- and social image concerns. Managers should be aware of this multiplicity of dimensions when deciding to release or withhold performance feedback to their employees.

\section{Peer effects on effort at work}

In the previous sections performance feedback was provided by an authority (a teacher, a manager). But in many work settings information about one's relative performance comes from the observation of peers. This does not mean that the dissemination of such social information is necessarily uncontrolled by an authority, since the way work is organized and incentives are designed favor observability or not. But the source of information is different. For the sake of concision, this section focuses on peer effects on effort at the workplace and omits peer effects in education, on participation in the labor market, recruitment and retirement decisions.

This section exposes first the challenges raised by the identification of peer effects. Then, it reviews field studies and finally, laboratory studies. Three main categories of mechanisms have been identified behind the spillover effects of interpersonal comparisons on productivity: image concerns, mutual monitoring and conformity to norms, competitive preferences and rivalry. The nature of these mechanisms depends partly on whether an individual's effort generates externalities on others' earnings and/or workload.

\subsection{The challenging identification of peer effects}

Peer effects at work have been the subject of early theoretical models. Kandel and Lazear (1992) model peer pressure in a team context with payoff externalities (see also Baron and Gjerde 1997). They show the role of effort observability on feelings of shame and guilt: when team members internalize the externalities caused by free riding, peer pressure can mitigate the free riding problem in teams.

Empirical evidence of peer effects is more recent because identifying peer effects is challenging (Manski 1993). When using linear-in-means models, a first big issue is that, usually, endogenous peer effects (i.e., the pure impact of others' behavior -their contemporaneous productivity, for example- on one's own behavior) cannot be disentangled from correlated effects (i.e., peers behave similarly because they face similar shocks or because of self-selection and homophily), and from contextual or exogenous peer effects (i.e., peers' exogenous characteristics -their permanent productivity, for example). The second big issue is the "reflection problem" originating in the fact that the behavior of individuals and peers is simultaneous. Individuals may be influenced by their peers but may also influence these peers, which leads to overestimate the size of peer effects. This cannot be solved by simply leaving out the individual from the average of his or her group since it would generate an exclusion bias leading to underestimate the size of peer effects. A third issue is measurement error in individuals' characteristics that may cause biased measurement of mean characteristics. The 
last challenge is the characterization of the mechanism behind endogenous peer effects (peer pressure, social learning, conformity, rivalry, etc.).

Although identification remains a challenge in the field, a number of econometric case studies has developed recently that address these issues. These studies consider settings characterized by a quasi-random assignment of workers to peer groups and quasi-experimental exogenous changes in incentives. Instrumental variables and selection models help address the selfselection issue. Some of these studies identify only exogenous peer effects, i.e., the impact of peers' permanent ability on individuals' contemporaneous productivity. For the identification of endogenous effects, various approaches are used, exploiting time discontinuity between peers' and individual's behavior, instrumental variables, or the network structure of interactions.

The control permitted by laboratory experiments is a serious advantage for the study of peer effects. First, it is possible to control for correlated effects notably by assigning randomly and exogenously subjects to treatments. The design of highly stylized protocols reduces the number of unobserved characteristics relevant to the situation. Second, it allows researchers to disentangle endogenous and exogenous peer effects. Finally, the anonymity of interactions and the exogenous manipulation of the social interaction structures, team composition, nature and flows of information, and incentive schemes help identify the mechanisms behind peer effects.

Laboratory experiments are respected for their strong internal validity but they are suspect of limited external validity. Herbst and Mas (2015) compare the estimates of peer effects on worker output in 11 laboratory experiments and 23 field studies. They estimate an average magnitude of peer effects of 0.13 (a one percent increase in average peers productivity increases worker productivity by 0.13 percent). This magnitude does not differ significantly between field (0.107) and lab studies (0.148). Moreover, the main features of production processes have a similar impact on productivity spillovers in laboratory and field studies. They conclude that results from the laboratory generalize to the field.

\subsection{Field evidence}

The vast majority of field studies find evidence of positive exogenous and endogenous peer effects at work: higher average peers' ability and effort increase individual's performance. This is not systematic. For example, Waldinger (2012) finds no peer effects in a study that exploits the dismissal of scientists by the Nazi regime in 1933 as a source of exogenous variation in group composition. The positive peer effects usually observed at work contrast with education where peer effects can be negative, depending on the image students are willing to display (e.g., Austen-Smith and Fryer 2005 on "Acting White"; Bursztyn and Jenson 2015; for surveys, see Epple and Romano 2011 and Sacerdote 2011). Mixed results have also been documented in sports (for negative peer effects, see Guryan, Kroft and Notowidigdo 2009 and Brown 2011 on golf tournaments; for positive effects, see Gould and Kaplan 2011 on baseball players, and Yamane and Hayashi 2015 on swimmers).

Another common finding is the heterogeneity of peer effects at work, depending on workers' ability. The mechanisms behind such peer effects vary across studies and depend on behavioral dimensions, such as individuals' preferences, as well as on the existence of payoff or technological externalities, thus on companies' human resources and organizational policies.

\subsubsection{Peer effects in the presence of payoff externalities}

Evidence of peer effects has been found in settings where individual effort entails payoff externalities on peers, for example through team bonuses, tournaments or risk of termination, but no externalities on the workload of peers. Firms' pay and termination policies affect 
spillovers by increasing the marginal return of effort. The mechanisms behind such peer effects can be collusion, social pressure and contagious enthusiasm.

In a fruit picking farm using a team-based work organization, Bandiera, Barankay and Rasul (2005) show the importance of social connections and social preferences in workers' response to incentives. Moving from relative performance pay to individual piece rates increases productivity by $50 \%$ on average. Under relative incentives, the more productive workers internalize the negative externalities their effort generates on their co-workers' pay and this effect is stronger when a larger share of co-workers are friends. By contrast, under individual piece rate one's effort does not impact directly others' pay and social connections no longer affect productivity. Internalization of externalities under relative incentives is found only when mutual monitoring is possible, i.e., when workers can observe each other. Thus, the mechanism behind internalization is collusion and not altruism.

Social pressure can also explain an increase in productivity when moving from an individual to a team incentive scheme. In field experiments where students were incentivized to study or exercise, Babcock et al. (2015) observe an increase in productivity of 9 to $17 \%$ when conditioning a bonus on both team members accumulating enough eligible visits to the library or the gym. A much lower effect when the teammate is anonymous invalidates altruism or guilt aversion toward strangers as primary drivers. Production complementarities and precommitment are rejected. Social pressure is the main candidate explanation: individuals comply more because they are willing not to disappoint their teammate and let their team down.

Contagious enthusiasm is another possible mechanism, as shown by Arpey (2014) in the study of a Chinese weaving company. Under competitive team bonuses, low productivity workers free ride less when a high productivity worker joins the team because it increases the chance of earning the team bonus. By contrast, an increase in the mean productivity of low ability peers has no impact if workers believe that the probability to earn the bonus remains too low.

On the opposite, negative productivity spillovers have been found in settings where the probability of being fired depends on the productivity of the inputs allocated to workers and their peers. Studying an egg producing company in Peru Amodio and Martinez-Carrasco (2018) exploit the quasi-random assignment of workers to batches of hens of various ages. The drop of productivity is one third standard deviation when the productivity of a worker's neighboring peers increases because they are assigned batches of younger hens. Higher peers' productivity reduces the probability of a given worker being fired: the marginal return from effort in terms of probability to keep one's job is reduced and this encourages free riding. Social relationships and incentives matter. Peer effects vanish when neighbors are friends or when the worker is assigned more productive hens and thus, is more likely to get an individual piece rate bonus.

\subsubsection{Peer effects in the presence of organizational and technological externalities}

Productivity spillovers have also been identified in settings where individual effort places no payoff externalities onto peers but generates externalities on peers' workload, for example when technology imposes effort complementarity or substitutability. Gould and Winter (2009) defend that pure income maximization can explain positive peer effects when efforts are complement and negative effects when they are substitutes. Behavioral mechanisms such as peer pressure and social learning can also generate peer effects by decreasing the marginal cost of effort.

Mas and Moretti (2009) use scanner data to measure the productivity of supermarket cashiers paid at a flat wage, and exploit quasi-random variations of the team composition. Free riding entails a negative externality on the workload of other cashiers. The introduction of an employee with a higher permanent productivity in the team results in a higher effort of the cashiers in the line of vision of this abler employee. Individual current productivity increases 
by $1.7 \%$ in reaction to a $10 \%$ increase in the productivity of co-workers. This exogenous effect is stronger if employees have more interactions. By contrast, there is no productivity spillover on the cashier located in the back of an abler employee (which excludes social learning). Spatial models identify that spillovers are driven by mutual monitoring. Being observed by more productive peers discourages free riding because of image concerns (see Bursztyn and Jensen 2017 for a survey on social image and social pressure).

Peer pressure may derive not only from the permanent ability of co-workers (exogenous effect) but also from their current level of effort (endogenous effect). For example, in an hospital emergency service working under a nurse-managed system, the presence of another physician in the pod reduces foot-dragging (Chan 2016). Exploiting the frequent exogenous recomposition of shifts among warehouse employees in a freight forwarding company, Steinbach and Tatsi (2018) disentangle the impact of peers' permanent vs. contemporaneous productivity on individual performance. Efforts are perfectly substitutable. The authors use 2SLS regressions and instrument the peers' characteristics of one's peers. In teams larger than nine employees, people work harder when peers have a higher point-in-time performance, whereas they free ride more when peers have a higher permanent productivity, especially when they share the same nationality - which contradicts Mas and Moretti (2009). Also, peers' contemporaneous productivity matters more for workers than their permanent ability.

Knowledge spillovers constitute another channel. The importance of productivity spillovers on team output has been established in settings with heterogeneity in effort and ability to help, when the ability to influence others' productivity does not necessarily depend on one's own productivity (see, e.g., Arcidiano, Kinsler and Price 2017 on basketball players). Using data from a call center, Lindquist, Sauermann and Zenou (2015) identify a local average network effect that represents either peer pressure or norm conformity. A $10 \%$ increase in the contemporaneous productivity of peer network raises the worker's current output by $1.7 \%$, with a stronger coefficient for low-tenure workers. They also identify a local aggregate effect that represents strategic complementarities and is generated by knowledge spillovers. Having in one's network one co-worker that attended an on-the-job training program increases a worker's productivity by $0.7 \%$. Thus, companies should retain people with the highest network intercentrality -who are not necessarily the most skilled- because they generate larger spillovers.

Social learning can explain the positive influence of peers with high permanent productivity (and the absence of influence of low performers) on the performance of workers even if they cannot see each other. This has been found in contexts as diverse as a service company where knowledge workers interact through digital communication channels (Kane, Ransbotham and Boynton 2015) and a Chinese textile firm where weavers work in isolation but exchange in team meetings and during after-work joint activities (Kato and Shu 2008). Kato and Shu (2008) show how group identity and networks influence the magnitude of knowledge spillovers within teams. De Grip and Sauermann (2012) measure the externalities of a training program in a call center on untreated workers. A $10 \%$ increase in the share of trained colleagues increase the performance of untreated employees by $0.5 \%$ (although only marginally significantly so).

The previous studies suggest that payoff or productive externalities change the nature of peer effects. But what happens when peers working in the same location are incentivized differently? To address this question, Chan, Li and Pierce (2014) use data from cosmetics counters of various brands in a Chinese department store. Salespeople work in teams that compete against one another for the store's customers. Those compensated with team sales commissions compete with peers from other brands, while those compensated with individual sales commissions have also to compete within the same brand. The identification assumption is that assignment to counters and to payment schemes is independent of ability. More able employees who are paid team-based commissions help more their less able peers from the same brand 
(positive spillover), which impacts negatively peers from other brands. By contrast, when paid individual-based commissions they become more competitive with peers from the same brand (negative spillover), with a lower impact on peers from the other brands. Because of peer effects, heterogeneity in employees' skills enhances the brand performance under team-based incentives and reduces it under individual-based incentives. Helping and rivalry are thus additional mechanisms behind peer effects.

\subsubsection{Peer effects in the absence of externalities}

Finally, peer effects have also been found in contexts without payoff or technological externalities. The mechanism behind such peer effects is consistent with conformity and socialization, close to the notion of social facilitation in psychology (Zajonc 1965).

Bandiera, Barankay and Rasul (2010) combine personal data and a survey to identify friendship links in a fruit picking farm. Due to frequent changes in the team composition (assumed to be independent from the unobserved determinants of productivity), the same workers are observed working sometimes with friends and sometimes with workers who do not belong to the same network, which enables the identification of a causal effect of networks. When workers are paid individual piece rates, working alongside a more able friend increases productivity by $10 \%$, while working alongside a less able friend decreases it by $10 \%$ (which means forgoing earnings). Overall, social connections have a positive net influence on the farm performance. In the absence of complementarities between workers, the channel of peer effects is conformity to a social norm that lies between the productivity of the most able and that of the less able workers. It derives from the fact that people enjoy working at close distance from their friends.

On the external margin peer effects can develop in opposite directions. Bradley, Green and Leeves (2007) illustrate norm compliance with data on absenteeism among teachers (see Ichino and Maggi 2000 on bank employees). A teacher's absenteeism increases by one day when the average number of days of absence of colleagues is at least 12. Also, salespersons' turnover probability increases with the turnover of peers, which is interpreted in terms of social identity theory (Sunder et al. 2017). On the other side, in an Indian call center the 5\% increase in the productivity of data entry workers generated by the presence of a co-worker with above average productivity operates through increased working time (Kaur, Kremer, and Mullainathan 2010). Interestingly, the authors identify a reduced demand for commitment contracts when workers have above average peers, suggesting that peer effects also mitigate self-control problems.

Overall a large majority of field studies find evidence of peer effects, driven either by collusion, peer pressure, social learning or normative conformity. An important question is whether peer effects on output translate into wage increases. Considering a local labor market instead of single companies and using employer-employee data instead of quasi-experiments, Cornelissen, Dustmann and Schönberg (2017) find very small peer effects in wages. But it is important to recall that the identification of productivity spillovers in econometric case studies relies on the crucial assumption of a random assignment of workers to peer groups that is orthogonal to the unobserved productive characteristics of workers.

\subsection{Laboratory evidence}

The laboratory guarantees the random assignment of players to groups or networks and limits measurement errors. While not all experiments find positive peer effects, the magnitude of the detected effects is very similar to that measured in the field (Herbst and Mas 2015). Like for field studies, some experiments exclude externalities while others introduce payoff or organizational externalities. They confirm in a controlled environment mechanisms such as conformity, rivalry or distributional preferences. 


\subsubsection{Peer effects in the absence of externalities}

A number of laboratory experiments have found evidence of peer effects driven by conformity in settings without payoff or productive externalities. Falk and Ichino (2006) recruited students for a one-shot four-hour job consisting of stuffing letters into envelopes. Subjects who are paid a flat wage are assigned randomly to the Single or the Pair condition. While in the former subjects work in isolation, in the latter two subjects work simultaneously in the same room, allowing for mutual influence. Positive peer effects are identified by means of three measures: the average output is $16.3 \%$ higher in pairs (only marginally significant); the within-pair standard deviation of output is smaller compared to the between-pair standard deviation; it is smaller in the true pairs compared to hypothetical pairs simulated from all possible configurations of individual observations from the Single condition. In other words, the output of two workers in the Pair condition is higher than the output of two subjects working separately. A one unit increase in the output of one worker increases by 0.14 unit the output of the co-worker. A quantile analysis shows that peer effects are larger for less productive subjects. This finding is more consistent with conformity to a productive norm than with contagious enthusiasm (which would have increased everyone's output).

Thöni and Gächter (2015) have designed a three-player gift-exchange game in which a principal determines the fixed wage given to two similar ability agents who then choose simultaneously an abstract level of effort. Agents can revise their choice after being informed about their peer's effort. To avoid the reflection problem, a random draw selects the initial effort of one agent and the revised effort of the other agent. Subjects revise effort downward after observing that their peer's effort is lower than their own. By contrast, observing a higher peer effort has limited effect, contrary to Falk and Ichino (2006). This cannot be rationalized by standard theories of social preferences based on intentions and distributional preferences that predict either no peer effects or strategic substitutability. This is more consistent with theories of social preferences that incorporate conformity, nom following or social esteem.

Conformity may also influence the extensive margin of effort provision. Rosaz, Slonim and Villeval (2016) designed an experiment where subjects have to decide when to quit. They manipulate whether subjects work alone or in the presence of a peer like in Falk and Ichino (2006), whether the subject is informed continuously on the evolution of the peer's performance or not, and whether communication is allowed or forbidden. Peers influence working time only when people can communicate, but not on performance. In this condition subjects stay longer and they quit at more similar times. This results from a sociability effect (like in Bandiera et al. 2010) and not from rivalry since peer's performance has no effect on quitting time.

Conformity may also produce negative peer effects. Bellemare, Lepage and Shearer (2010) study the interactions between incentive schemes, peer pressure and gender in an experiment where subjects perform a data entry task. Subjects are informed or not on the productivity of a peer who participated in a past session, which enables the estimation of non-linearities in the response to peer pressure without any reflection issue. No positive peer effects are found under any pay scheme for any gender. On the contrary, a very high or a very low peer's performance reduce the output of males who are paid a fixed wage. The negative effect of a low peer pressure may result from conformity, and the negative effect of a high pressure from discouragement. Both effects are turned off when a piece rate scheme motivates workers to do their best to earn more regardless of social information.

Peer effects can result from rivalry instead of conformity. Using linear-in-means models, Beugnot et al. (2019) identify peer effects by exploiting the structure of interactions. They compare directed vs. undirected networks in a setting where subjects are paid a piece rate for performing an addition task without any productive externality. This contrasts with most 
previous tests in which individuals interact in groups, i.e., individuals are influenced by all other group members and by no one outside. In directed networks, subjects learn the mean score of peers who performed the same task in the past. Social information flows unidirectionally, avoiding the reflection problem. In undirected networks, subjects and their peers perform the task simultaneously. Information flows bidirectionally and a convergence process is introduced to address simultaneity. Peer effects increase the productivity of males in both types of networks and to the same extent. By contrast, females disregard peers' performance when information flows both ways while they react like males to social information in the directed networks. These peer effects are consistent with rivalry and competitiveness.

\subsubsection{Peer effects in the presence of externalities}

In the presence of payoff externalities, distributional preferences can generate peer effects since one's effort impacts co-workers' wage. Considering two teams playing independent public goods games, Sausgruber (2009) observes a correlation between the average contribution in teams when social information is transmitted to the other team, leading to higher homogeneity of contributions within paired teams. This correlation contributes to reduce overall earnings inequality although in this setting, there are direct payoff externalities of effort within the team but not with the other team that is used as example. Mohnen, Pokorny, Sliwka (2008) show theoretically and with a real-effort experiment in a teamwork setting that inequality aversion explains the peer pressure associated with interim observability of peer's performance. Pairs of workers are compensated with a piece rate applied to the team output. Without interim observability inequality aversion does not affect behavior, but with transparency it discourages free riding by inducing inequality averse agents to work harder from the beginning. Indeed, with interim observability higher effort increases the marginal return of effort because an inequality averse teammate lagging behind increases future effort; moreover, inequality averse frontrunners can sanction their teammate by reducing their own effort. Since people suffer usually more from disadvantageous than from advantageous inequality, front runners decrease their effort and laggards increase it, but to a lesser extent.

In these previous studies, subjects observe others and are observed by others at the same time; it is thus not possible to disentangle between the two. Some studies in the field have shown, however, that the two effects may differ, which suggests that inequality aversion cannot explain all peer effects. Two experiments try to disentangle peer effects driven by the observability of peers and peer effects driven by being observed, replicating in a controlled environment a similar work setting as in Mas and Moretti (2009).

Georganas, Tonin and Vlassopoulos (2015) vary across treatments whether subjects perform a slider task in isolation, or are observed by peers but do not observe anyone, or observe peers but cannot be observed by them. Workers are compensated by an individual piece rate or by a team piece rate applied to the average performance of the team of three, turning on and off the presence of payoff externalities. Positive peer effects are found when subjects are observed but only in the first periods and under team-based pay, with an overall null effect. The pressure induced by observability reduces the initial free-riding but only in the presence of externalities. No peer effects are found when observers are paid a team piece rate, possibly because observers do not feel peer pressure. By contrast, under an individual piece rate there is a U-shape relationship between observers' and observed peers' performance that can result from conformism (when comparing to higher performers) and rivalry (when comparing to lower performers). These non-linearities are in contrast with those found by Bellemare et al. (2010).

Van Veldhuizen, Oosterbeek and Sonnemans (2018) consider instead team production with no payoff externality but with productive substitutability. Four workers have to solve a given number of addition problems and are paid a fixed wage. Depending on the treatment, they are 
able or not to learn the baseline productivity of peers. Depending on their position in the team, they are able or not to observe the current productivity of one peer and be observed by another peer while performing the task. The results are in contrast with Falk and Ichino (2006) and Georganas et al. (2015), as subjects' output does not increase in the productivity of peers. They also differ from Mas and Moretti (2009), as being observed by a more productive peer does not increase subjects' output. Finally, lower performers do not react more positively to their peers' productivity than high performers, as some of them increase effort while others take the opportunity of being matched with a high performer to free ride.

To sum up, a majority of studies find that people are sensitive to the exogenous characteristics and the endogenous behavior of their peers and react positively to them both at the intensive and at the extensive margin of effort. The estimates of the size of productivity spillovers is similar across studies conducted in naturally-occurring environments or in the laboratory. Many studies find heterogeneous effects of peers in the performance distribution, depending on the presence of payoff or technological externalities of individual effort on co-workers. This diversity helps identify various mechanisms generating such peer effects: conformity to norm, peer pressure, social learning, and inequity aversion. Managers should take into account these dimensions when designing incentive schemes and the spatial organization of workspace.

\section{Conclusion}

Motivating employees is a major challenge for companies. In theory, when interests are not aligned between principal and agents, monetary incentive schemes can be designed to achieve this goal. But in practice, incentives may not be sufficient and sometimes they may be counterproductive. The provision of information on how well employees perform in absolute terms or relatively to others may constitute an additional lever of action. However, designing efficient informational policies is complex. Feedback can increase productivity, especially if employees are motivated by social comparisons. But it may be detrimental if low performers lose self-confidence or if it triggers jealousy among employees. Another source of complexity comes from the possible heterogeneity of feedback effects according to employees' skills. It is thus important to combine monetary and informational incentives in a way that is beneficial both from an individual and from an organizational point of view.

This paper surveys evidence from behavioral and experimental economic studies that investigate the effects of performance feedback and productivity spillovers on employees' effort. This literature has provided robust evidence on the impact of absolute and relative performance feedback and on the importance of peers on individuals' achievements. Absolute performance feedback has both a cognitive and a motivational impact on individuals. It helps them evaluate more precisely their cost and return to effort when they have imperfect knowledge of their ability. It also fosters intrinsic motivation, especially when associated with signals of recognition. Because of that, principals may decide to release or withhold information and if they release it, they may distort it. Leniency and centrality are biases typically encountered in performance appraisals.

Many field and lab studies identify positive effects of relative performance feedback on effort. These effects are larger when combined with performance pay schemes but they may generate the incentive effects of tournaments even without monetary prizes. They are heterogeneous, depending on the individuals' relative ability. The mechanisms behind such effects are selfconfidence and ego-utility, status concerns and competitive preferences, and social pressure when feedback is managed as a monitoring device within teams. However, relative feedback may also have detrimental consequences. For top performers, this might result in choking under pressure, collusion and conformity to social norms, and for lower performers, disappointment aversion and discouragement. Other negative aspects are effort distortion and anti-social 
behavior toward co-workers. Laboratory experiments also reveal the complex aspects of motivated confidence management through biased belief updating when feedback provides information that individuals prefer not to know.

Finally, this paper highlights the importance of peer effects at work. Importantly, the estimates of the size of productivity spillovers are similar across studies conducted in naturally-occurring environments or in the laboratory. This is a major finding because, when positive, these peer effects increase the return to social capital and contribute to economic growth. The valence of peer effects is heterogeneous in the performance distribution and it depends notably on the existence of task or payoff complementarities. Peer effects are triggered by various mechanisms: collusion and social preferences, especially in the presence of payoff externalities, peer pressure and social learning, especially in the presence of technological or organizational externalities, and conformity and rivalry in the absence of any direct externalities.

This multiplicity of dimensions has major implications for companies when deciding to release or withhold performance feedback to their employees and when designing incentive schemes and workspace organization. For example, providing relative feedback to the lowest and the best performers may increase their performance, but it can be counterproductive for the workers in the middle of the distribution if they have a taste for rank. Through an appropriate workspace organization, firms can exploit productivity spillovers and avoid negative externalities. This is, however, more challenging if endogenous and exogenous peer effects work in opposite directions. The composition of teams should also take into account the social relationships between peers, as social proximity can facilitate knowledge spillovers, but it may also encourage compliance with a norm of low productivity.

Many aspects of feedback remain unknown, however. Further research should investigate in particular how frequent and durable feedback should be to sustain effort optimally. It is unclear if continuous feedback is better than intermittent feedback, or than feedback provided when a significant evolution is observed. Relatively little is known about the optimal degree of precision of feedback in order to avoid discouragement, and how durable the effects of feedback can be. Also, most of the existing studies in the field consider a single category of jobs, usually relatively low skilled. It would be interesting to explore the effects of feedback for a wider range of jobs, characterized by various degrees of skill intensity. Also, the literature has shown how biased individuals can be when they update their beliefs about their ability after receiving feedback; it would be interesting to analyze the extent to which teams are also prone to such biases.

Regarding peer effects, open questions remain about the optimal work organization, notably the optimal size of groups and the structure of networks, in order to facilitate social learning and knowledge spillovers among workers. A few studies invoke the importance of social relationships in the dissemination of peer effects. However, the way group identity and social segmentation influences the dissemination of productivity spillovers remains largely unknown. More investigation on the way peer effects translate into wages is also needed. The surveyed literature shows that social preferences interact with incentive schemes to trigger productivity spillovers. But the opposite relationship has been little explored, i.e., how peer effects influence the evolution of social preferences at the workplace. A better understanding of these interactions would certainly contribute to the building of more efficient labor relationships. 


\section{References}

Ager P, Bursztyn L, Voth H-J (2016) Killer incentives: Status competition and pilot performance during World War II. NBER Working Paper 22992 http://www.nber.org/papers/w22992

Alos-Ferrer C, Garcia-Segarra J, Ritschel A (2018) Performance curiosity. J Econ Psychol 64: $1-17$

Amodio F, Martinez-Carrasco MA (2018) Input Allocation, Workforce Management and Productivity Spillovers: Evidence from Personnel Data. Rev Econ Stud 85 (4) 1937-1970

Andrabi T, Das J, Ijaz Khwaja AI (2017) Report cards: The impact of providing school and child test scores on educational markets. Am Econ Rev 107 (6): 1535-1563

Arcidiacono P, Kinsler J, Price J (2017) Productivity Spillovers in Team Production: Evidence from Professional Basketball. J Labor Econ 35 (1): 191-225

Arpey N (2014) Peer Effects Among Weavers: Evidence from a Chinese Textile Firm with a Relative Group Incentive Scheme. Mimeo, Colgate University. http://blogs.colgate.edu/economics/files/2014/09/Arpey-2014-Peer-Effects-among-

Weavers.pdf

Arnold HJ (1976) Effects of performance feedback and extrinsic reward upon high intrinsic motivation. Organ Behav Hum Perf 17 (2): 275-288

Ashraf A (2018) Do Performance Ranks Increase Productivity? Evidence from a Field Experiment. Mimeo, University of Warwick

Ashraf N, Bandiera O, Lee SS (2014) Awards unbundled: evidence from a natural field experiment. J Econ Behav Organ 100: 44-63

Auriol E, Renault R (2008) Status and Incentives. Rand J Econ 39 (1): 305-326

Austen-Smith D, Fryer RG (2005) An Economic Analysis of Acting White. Q J Econ 120 (2): $551-583$

Aoyagi M (2010) Information feedback in a dynamic tournament. Games and Economic Behavior 70 (2): 242-260

Azmat G, Iriberri N (2010) The importance of relative performance feedback information: Evidence from a natural experiment using high school students. J Publ Econ 94(5): 797-811

Azmat G, Iriberri N (2016) The provision of relative performance feedback: An analysis of performance and satisfaction. J Econ Manage Strat 25(1): 77-110

Azmat G, Bagues M, Cabrales A, Iriberri N (2019) What you don't know... can't hurt you: A field experiment on relative performance feedback in higher education. Manag Sci

Babcock P, Bedard K, Charness G, Hartman J, Royer H (2015) Letting down the Team? Social Effects of Team Incentives. J Eur Econ Ass 93: 841-870

Bandiera O, Barankay I, Rasul I (2005) Social Preferences and the Response to Incentives: Evidence from Personnel Data. Q J Econ 120 (3): 917-962

Bandiera O, Barankay I, Rasul I (2010) Social incentives in the workplace. Rev Econ Stud 77 (2): $417-458$

Bandiera O, Barankay I, Rasul I (2013) Team incentives: Evidence from a firm level experiment. J Eur Econ Assoc 11(5): 1079-1114 
Bandiera O, Larcinese V, Rasul I (2015) Blissful ignorance? A natural experiment on the effect of feedback on students' performance. Labour Econ 34: 13-25

Banerjee R, Datta Gupta N, Villeval MC (2018) Self-confidence spillovers and motivated beliefs. GATE Working Paper 2018-06, Lyon http://ssrn.com/abstract=3157467

Barankay I (2011) Rankings and social tournaments: Evidence from a crowd-sourcing experiment. Mimeo, University of Pennsylvania. https://repository.upenn.edu/mgmt_papers/265

Barankay I (2012) Rank Incentives: Evidence From a Randomized Workplace Experiment. Wharton School. Mimeo, University of Pennsylvania

Baron JM, Gjerde KP (1997) Peer pressure in an agency relationship. J Labor Econ 15 (2): 234254

Bellemare C, Lepage P, Shearer B (2010) Peer pressure, incentives, and gender: an experimental analysis of motivation in the workplace. Labour Econ 17 (1): 276-283

Bellemare C, Sebald A (2019) Self-confidence and reactions to subjective performance evaluations. IZA Discussion Paper No. 12215

Bénabou R, Tirole J (2002) Self-confidence and personal motivation. Q J Econ 117 (3): 871915

Berger J, Harbring C, Sliwka D (2013) Performance appraisals and the impact of forced distribution - an experimental investigation. Manag Sci 59 (1): 54-68

Berger L, Fiolleau K, MacTavish C (2019) I Know Something You Don't Know: The Effect of Relative Performance Information and Individual Performance Incentives on Knowledge Sharing. J Manage Accounting Research 31 (2): 19-35

Besley T, Ghatak M (2008) Status Incentives. Am Econ Rev 98 (2): 206-211

Beugnot J., Fortin B., Lacroix G., Villeval MC (2019) Gender and Peer Effects on Performance in Social Networks. Eur Econ Rev 113: 207-224

Blader S, Gartenberg C., Prat A (2019) The contingent effect of management practice. Rev Econ Stud

Blanes i Vidal J, Nossol M (2011) Tournaments without prizes: Evidence from personnel records. Manag Sci 57 (10): 1721-1736

Bol JC (2011) The Determinants and Performance Effects of Managers' Performance Evaluation Biases. Account Rev 86 (5): 1549-1575

Brade R, Himmler O, Jackle R (2018) Normatively framed relative performance feedback field experiment and replication. MPRA Discussion Paper No. 88830

Bradler C , Dur R, Neckermann S, Non A (2016) Employee recognition and performance: a field experiment. Manag Sci 62 (11): 3085-3099

Bradley S, Green C, Leeves G (2007) Worker absence and shirking: Evidence from matched teacher-school data. Labour Econ 14 (3): 319-334

Breuer K, Nieken P, Sliwka D (2013) Social ties and subjective performance evaluations: An empirical investigation. Rev Manag Sci 2

Brown J (2011) Quitters Never Win: The (Adverse) Incentive Effects of Competing with Superstars. J Polit Econ 119: 982-1013 
Burks SV, Carpenter JP, Goette L, Rustichini A (2013) Overconfidence and Social Signalling. Rev Econ Stud 80 (3): 949-983

Burgers C, Eden A, van Engelenburg MD, Buningh S (2015) How feedback boosts motivation and play in a brain-training game. Comput Hum Behav 48: 94-103

Bursztyn L, Jensen R (2015) How Does Peer Pressure Affect Educational Investments? Q J Econ 130 (3): 1329-1367

Bursztyn L, Jensen R (2017) Social image and economic behavior in the field: identifying, understanding and shaping social pressure. Annu Rev Econ 9: 131-153

Buser T, Gerhards L, van der Weele J (2018) Responsiveness to Feedback as a Personal Trait. J Risk Uncert, 56(2): 165-192

Buurman M, Delfgaauw J, Dur R, Zoutenbier R (2020) When Do Teachers Respond to Student Feedback? Evidence from a Field Experiment. IZA Discussion Paper No.12907

Cabrera JM, Cid A (2017) Gender Differences to Relative Performance Feedback: A Field Experiment in Education. Working Papers 1704, Facultad de Ciencias Empresariales y Economia, Universidad de Montevideo

Cadsby CB, Engle-Warnick J, Fang T, Song F (2019) Invoking social comparison to improve performance by ranking employees: The moderating effects of public ranking, rank pay, and individual risk attitude. J Econ Psychol 72: 64-79

Casas-Arce P, Martinez-Jerez FA (2009) Relative Performance Compensation, Contests, and Dynamic Incentives. Manag Sci 55 (8): 1306-1320

Celik Katreniak D (2018) Dark Side of Incentives: Evidence from a Randomized Control Trial in Uganda. Available at SSRN: https://ssrn.com/abstract=3288474

Chan TY, Li J, Pierce L (2014) Compensation and Peer Effects in Competing Sales Teams. Manag Sci 60 (8): 1965-1984

Chan DC (2016) Teamwork and Moral Hazard: Evidence from the Emergency Department. J Pol Econ 124 (3): 734-770

Charness G, Masclet D, Villeval MC (2014) The dark side of competition for status. Manag Sci 60(1) : 38-55

Chew SH, Huang W, Zhao X (2019) Motivated false memory. Mimeo, National University of Singapore, http://dx.doi.org/10.2139/ssrn.2127795

Cornelissen T, Dustmann C, Schönberg U (2017) Peer Effects in the Workplace. Am Econ Rev 107 (2): 425-456

Cotofan M (2019) Leaning from praise: Evidence from a field experiment with teachers. Mimeo Tinbergen Institute

Delfgaauw J, Dur R, Sol J, Verbeke W (2013), Tournament Incentives in the Field: Gender Differences in the Workplace. J Labor Econ 31 (2): 305-326

Dobrescu LI, Faravelli M, Megalokonomou R, Motta A (2019) Rank Incentives and Social Learning: Evidence from a Randomized Controlled Trial. IZA DP No. 12437, Bonn

Drouvelis M, Paiardini P (2019) Feedback quality and performance in organisations. Mimeo, University of Birmingham

Ederer F (2010) Feedback and Motivation in Dynamic Tournaments. J Econ Manage Strat 19 (3): 733-769 
Ederer F, Fehr E (2007) Deception and incentives: How dishonesty undermines effort provision. University of Zurich Institute for Empirical Research in Economics Working Paper No. 341

Eil D, Rao JM (2011) The good news-bad news effect: Asymmetric processing of objective information about yourself. Am Econ J-Mic 3: 114-138

Ellingsen T, Johannesson M (2007) Paying respect. J. Econ. Perspect. 21(4):135-150

Epple D, Romano RE (2011) Peer Effects in Education: A Survey of the Theory and Evidence. In Handbook of Social Economics, edited by Jess Benhabib, Alberto Bisin, and Matthew O. Jackson, 1053-1163. Elsevier

Eriksson T, Poulsen A, Villeval MC (2009) Feedback and incentives: experimental evidence. Labor Econ 16 (6): 679-688

Eriksson T, Villeval MC (2012) Respect and relational contracts. J Econ Behav Org 81: 286298

Ertac S (2011) Does self-relevance affect information processing? Experimental evidence on the response to performance and non-performance feedback. J Econ Behav Org 80: 532-545

Ertac S, Koçkesen L, Ozdemir D (2016) The role of verifiability and privacy in the strategic provision of performance feedback: theory and experimental evidence. Game Econ Behav 100: $24-45$

Ertac S, Gümren M, Koçkesen L (2019) Strategic feedback in teams: theory and experimental evidence. J Econ Behav Org 162: 1-23

Falk A, Ichino A (2006) Clean evidence on peer effects. J Labor Econ 24 (1): 39-57

Fallucchi F, Renner E, Sefton M (2013) Information Feedback and Contest Structure in Rentseeking Games. Eur Econ Rev 64: 223-240

Fershtman C, Gneezy U (2011) The tradeoff between performance and quitting in high power tournaments. J. Eur. Econ. Assoc. 9(2): 318-336

Festinger L (1954) A theory of social comparison processes. Hum Relat 7: 117-140

Fischer M, Wagner V (2018) Effects of Timing and Reference Frame of Feedback: Evidence from a Field Experiment in Secondary Schools. Working Paper 1820, Gutenberg School of Management and Economics, Johannes Gutenberg-Universität Mainz

Freeman RB, Gelber AM (2010). Prize structure and information in tournaments: Experimental evidence. Am Econ J-Appl Econ 2 (1): 149-164.

Gershkov A, Perry M (2009) Tournaments with Midterms Reviews. Game Econ Behav 66 (1): $162-190$

Genakos C, Pagliero M (2012) Interim rank, risk taking, and performance in dynamic tournaments. J Political Econ 120(4): 782-813

Georganas S, Tonin M, Vlassopoulos M (2015) Peer pressure and productivity: the role of observing and being observed. J Econ Behav Org 117 (C): 223-232

Gerhards L, Siemer N (2016) The impact of private and public feedback on worker performance: Evidence from the lab. Econ Inq 54(2): 1188-1201

Gibbs MJ (1991) An Economic Approach to Process in Pay and Performance Appraisals. Harvard Business School. Mimeo 
Gill D, Kissova Z, Lee J, Prowse V (2018) First-place loving and last-place loathing: How rank in the distribution of performance affects effort provision. Manag Sci, doi:10.2139/ssrn.2641875

Gill D, Prowse V (2012) A structural analysis of disappointment aversion in a real effort competition. Am Econ Rev 102 (1): 469-503

Goulas S, Megalokonomou R (2018) Knowing who you actually are: The effect of feedback on short and long term outcomes. University of Warwick - Warwick Economics Research Papers Series No. 1075

Gould ED, Kaplan TR (2011) Learning Unethical Practices from a Co-worker: The Peer Effect of Jose Canseco. Labour Econ 18: 338-348

Gould ED, Winter E (2009) Interactions between Workers and the Technology of Production: Evidence from Professional Baseball. Rev Econ Stud 91 (1): 188-200

De Grip A, Sauermann J (2012) The effects of training on own and co-worker productivity: Evidence from a field experiment. Econ J 122: 376-399

Gürtler O, Harbring C (2010) Feedback in tournaments under commitment problems: experimental evidence. J Econ Manage Strat 19 (3): 771-810

Guryan J, Kroft K, Notowidigdo MJ (2009) Peer effects in the workplace: evidence from random groupings in professional golf tournaments. Am Econ J-Appl Econ 1 (4): 34-68

Haenni S (2019) Ever tried. Ever failed. No matter? On the demotivational effect of losing in repeated competitions. Game Econ Behav doi:10.1016/j.geb.2019.03.012

Hannan RL, Krishnan R, Newman AH (2008) The effects of disseminating relative performance feedback in tournament versus individual performance compensation plans. Account Rev 83 (4): 893-913

Hannan RL, McPhee GP, Newman AH, Tafkov ID (2013) The Effect of Relative Performance Information on Performance and Effort Allocation in a Multi-Task Environment. Account Rev 88 (2): $553-575$

Herbst D, Mas A (2015) Peer effects on worker output in the laboratory generalize to the field. Science 350 (6260): 545-549

Hermes H, Huschens M, Rothlauf F, Schunk D (2019) Motivating low achievers - Relative performance feedback in primary schools. NHH Discussion Paper SAM 14/19

Heursen L (2019) Does Relative Performance Information Lower Group Morale? Mimeo, Humboldt University of Berlin

Huang L, Murad Z (2019) Feedback spillover effect on competitiveness across unrelated tasks. Behav Research in Accounting https://doi.org/10.2308/bria-52583

Huffman D, Raymond C, Shvets J (2019) Persistent Overconfidence and Biased Memory: Evidence from Managers. Mimeo

Ichino A, Maggi G (2000) Work Environment and Individual Background: Explaining Regional Shirking Differentials in a Large Italian Firm. Q J Econ 115 (3): 1057-1590

Jalava N, Joensen JS, Pellas E (2015) Grades and rank: Impacts of non-financial incentives on test performance. J. Econom. Behav. Organ. 115:161-196

Kajitani S, Morimoto K, Suzuki S (2019) Information feedback in relative grading: Evidence from a field experiment. Meisei University Discussion Paper 40 
Kandel E, Lazear EP (1992) Peer pressure and partnerships. J Pol Econ: 801-817

Kane GC, Ransbotham S, Boynton, A (2015) Is high performance contagious among knowledge workers? Working Paper

\section{https://pdfs.semanticscholar.org/30b2/b9951f6b920f975b44e6821720e4f99e13f5.pdf}

Kato T, Shu P (2008) Performance Spillovers and Social Network in the Workplace: Evidence from Rural and Urban Weavers in a Chinese Textile Firm. IZA Discussion Paper No. 3340

Kaur S, Kremer M, Mullainathan S (2010) Self-Control and the Development of Work Arrangements. Am Econ Rev 100 (2): 624-628

Kluger AN, Denisi A (1996) The Effects of Feedback Interventions on Performance: A Historical Review, a Meta-analysis and a Preliminary Feedback Intervention Theory. Psychol Bull 119: 254-284

Kosfeld M, Neckermann S (2011) Getting More Work for Nothing? Symbolic Awards and Worker Performance. Am Econ J-Mic 3: 86-99

Kószegi B (2006) Ego Utility, Overconfidence, and Task Choice. J Eur Econ Assoc 4: 673-707

Kuhnen CM, Tymula A (2012) Feedback, self-esteem, and performance in organizations. Manag Sci 58 (1): 94-113.

Levitt S, List J, Neckermann S, Sadoff S (2016) The behavioralist goes to school: Leveraging behavioral economics to improve educational performance. Am Econ J-Econ Polic 8(4): 183219

Lindquist M, Sauermann J, Zenou Y (2015) Network effects on worker productivity. CEPR Discussion Paper No. 10928

Lizzeri A, Meyer M, Persico N (2002) The Incentive Effects of Interim Performance Evaluations. CARESS Working Paper; 02-09

Locke EA, Latham GP (1990) A Theory of Goal Setting and Task Performance. Englewood Cliffs, NJ , Prentice Hall

London M (2003) Job Feedback: Giving, Seeking and Using Feedback for Performance Improvement. Mahway, NJ: Lawrence Erlbaum Associates

Lount RB Jr, Wilk SL (2014) Working harder or hardly working? Posting performance eliminates social loafing and promotes social laboring in workgroups. Manage Sci. 60(5): 1098-1106

Ludwig S, Lünser GK (2012) Observing Your Competitor-The Role of Effort Information in Two-stage Tournaments. J Econ Psychol 33: 166-182

Mago SD, Samek AC, Sheremeta RM (2016) Facing Your Opponents: Social Identification and Information Feedback in Contests. J Conflict Resolut 60(3): 459-481

Manski CF (1993) Identification of endogenous social effects: the reflection problem. Rev Econ Stud 60 (3): 531-542

Marchegiani L, Reggiani T, Rizzolli M (2016) Loss averse agents and lenient supervisors in performance appraisal. J Econ Behav Organ 131: 183-197

Mas A, Moretti E (2009) Peers at work. Am Econ Rev 99 (1): 112-145

Möbius MM, Niederle M, Niehaus P, Rosenblat TS (2007), Gender Differences in Incorporating Performance Feedback. Mimeo, Harvard University 
Möbius MM, Niederle M, Niehaus M, Rosenblat TS (2011) Managing self-confidence: theory and experimental evidence. NBER WP 17014. National Bureau of Economic Research

Mohnen A, Pokorny K. (2006) Is honesty the best policy? An experimental study on the honesty of feedback in employer-employee relationships. Working Paper University of Cologne

Mohnen A, Pokorny K, Sliwka D (2008) Transparency, Inequity Aversion, and the Dynamics of Peer Pressure in Teams - Theory and Evidence. J Labor Econ 26 (4): 693-720

Moore D, Klein W (2008) Use of absolute and comparative performance feedback in absolute and comparative judgments and decisions. Organ Behav Hum Dec 107(1): 60-74

Moldovanu B, Sela A, Shi X (2007) Contests for Status. J Polit Econ 115(2): 338-363

Murphy KR, Cleveland JN (1991) Performance appraisal: An organizational perspective. Boston: Allyn and Bacoon

Nadler D (1979) The effects of feedback on task group behavior: A review of the experimental research. Organ Behav Hum Perf 23(3): 309-338

Newman AH, Tafkov I (2014) Relative Performance Information in Tournaments with Different Prize Structures. Account Org Soc 39 (5): 348-361

Nordstrom R, Lorenzi P, Hall RV (1990). A review of public posting of performance feedback in work settings. J Organ Behav Man 11 (2): 101-124

Pearce JL, Lyman WP (1986) Employee Responses to Formal Performance Appraisal Feedback. J Appl Psychol 71 (2): 211

Prendergast C (1999) The Provision of Incentives in Firms. J Econ Lit 37: 7-63

Rosaz J (2012) Biased information and effort. Econ Inq 50 (2): 484-501

Rosaz J, Villeval MC (2012) Lies and Biased Evaluation: A Real-Effort Experiment. J Econ Behav Organ 84 (2): 537-549

Rosaz J, Slonim R, Villeval MC (2016) Quitting and peer effects at work. Labour Econ 39: 5567

Rose JP, Windschitl PD (2008) How egocentrism and optimism change in response to feedback in repeated competitions. Org Behav Hum Dec 105(2): 201-220

Sacerdote B (2011) Peer Effects in Education: How Might They Work, How Big Are They and How Much Do We Know Thus Far? In Hanushek E, Machin S, Woessmann L (eds) Handbook of the Economics of Education 3:249-277, Elsevier

Sausgruber R (2009) A note on peer effects between teams. Exper Econ 12(2): 193-201

Schleicher DJ, Bull RA, Green SG (2009) Rater reactions to forced distribution rating systems. J. Management 35(4): 899-927

Sebald A, Walzl M (2014) Subjective Performance Evaluations and Reciprocity in PrincipalAgent Relations. Scan J Econ 116 (2): 570-590

Smith R (2000) Assimilative and contrastive emotional reactions to upward and downward social comparisons. In: Suis J and Wheeler L (eds) Handbook of Social Comparison: Theory and Research. Kluwer Academic/Plenum Publishers, New York, p 173-200

So T, Brown P, Chaudhuri A, Ryvkin D, Cameron L (2017) Piece-rates and tournaments: Implications for learning in a cognitively challenging task. J Econ Behav Organ 142: 11-23 
Steinbach D, Tatsi E (2018) Peer Effects, Free-Riding and Team Diversity. Working Paper https://pdfs.semanticscholar.org/9ef8/a475a706a899c11f22de27fe5aef632a53f0.pdf

Stinebrickner T, Stinebrickner R (2012) Learning about academic ability and the college dropout decision. J Labor Econ 30 (4): 707-748

Sunder S, Kumar V, Goreczny A, Maurer T (2017) Why Do Salespeople Quit? An Empirical Examination of Own and Peer Effects on Salesperson Turnover Behavior. J Marketing Res 54 (3): $381-397$

Tafkov I (2013) Private and Public Relative Performance Information under Different Compensation Contracts. Account Rev 88 (1): 327-350

Thöni C, Gächter S (2015) Peer effects and social preferences in voluntary cooperation: a theoretical and experimental analysis. J Econ Psychol 48:72-88.

Tran A, Zeckhauser R (2012) Rank as an inherent incentive: Evidence from a field experiment. J. Publ. Econ. 96(9): 645-650

Triplett N (1898) The Dynamogenic Factors in Pacemaking and Competition. Am J Psychol 9(4): 507-533

van Veldhuizen R, Oosterbeek H, Sonnemans J (2018) Peers at work: Evidence from the lab. PLoS ONE 13 (2): e0192038. https://doi.org/10.1371/journal.pone.0192038

Waldinger F (2012) Peer Effects in Science: Evidence from the Dismissal of Scientists in Nazi Germany. Rev Econ Stud 79 (2): 838-861

Wozniak D, Harbaugh WT, Mayr U (2014) The menstrual cycle and performance feedback alter gender differences in competitive choice. J Labor Econ 32(1): 161-198

Yamane S, Hayashi, R (2015) Peer Effects among Swimmers. Scand. J. Econ 117(4): 12301255

Zajonc RB (1965) Social facilitation. Science 149(3681) : 269-274

Zimmermann F (2019) The dynamics of motivated beliefs. Am. Econ. Rev. 


\section{APPENDIX}

(available at: http://www.gate.cnrs.fr/survey-feedback)

Table 1. Field studies on the effect of feedback on absolute performance

\begin{tabular}{|c|c|c|c|c|}
\hline Studies & Context & Nature of feedback & Incentives & Main effects on performance \\
\hline $\begin{array}{l}\text { Bandiera,Larcinese, } \\
\text { Rasul (2015) }\end{array}$ & $\begin{array}{l}\text { University UK - } \\
7738\end{array}$ & Past exam score & Individual grades & $\begin{array}{l}(+) \text { future exam score. Stronger for more able and } \\
\text { less informed students. Substitution effect }\end{array}$ \\
\hline Bol (2011) & $\begin{array}{l}\text { Financial service } \\
\text { provider Holland - } \\
198\end{array}$ & $\begin{array}{l}\text { Annual subjective ratings by } \\
\text { managers }\end{array}$ & $\begin{array}{l}\text { Flat pay }+ \text { bonus } \\
\text { up to } 15 \% \\
\text { function of rating }\end{array}$ & $\begin{array}{l}(-) \text { effect of compression bias on future } \\
\text { performance, due to decreased incentives. }(+) \\
\text { effect of leniency bias, due to fairness }\end{array}$ \\
\hline $\begin{array}{l}\text { Breuer, Nieken, } \\
\text { Sliwka (2013) }\end{array}$ & $\begin{array}{l}\text { Call center } \\
\text { Germany - } 520\end{array}$ & $\begin{array}{l}\text { Annual subjective assess- } \\
\text { ments and objective } \\
\text { measures of performance }\end{array}$ & Flat pay & $\begin{array}{l}\text { More leniency when longer interactions and in } \\
\text { smaller units where social ties between rater and } \\
\text { employee are closer }\end{array}$ \\
\hline $\begin{array}{l}\text { Stinebrickner,Stine- } \\
\text { brickner (2012) }\end{array}$ & $\begin{array}{l}\text { University US - } \\
325\end{array}$ & $\begin{array}{l}\text { 1st semester grade point } \\
\text { GPA (grade point average) }\end{array}$ & Individual grades & $\begin{array}{l}\text { (-) encourages the drop-out of students with } \\
\text { overoptimistic beliefs. Information channel }\end{array}$ \\
\hline
\end{tabular}

Notes: Greyed cells correspond to studies in the domain of education. Numbers correspond to the number of participants. 
Table 2. Laboratory experiments on the effects of feedback on absolute performance

\begin{tabular}{|c|c|c|c|c|}
\hline Studies & Context & Nature feedback & Incentives & Main effects on performance \\
\hline $\begin{array}{l}\text { Bellemare, Sebald } \\
\text { (2019) }\end{array}$ & $\begin{array}{l}\text { Clicking task } \\
\text { Denmark - } 1666\end{array}$ & $\begin{array}{l}\text { Unverifiable subjective } \\
\text { evaluation in deciles }\end{array}$ & $\begin{array}{l}\text { Flat or depending } \\
\text { on evaluation }\end{array}$ & $\begin{array}{l}\text { Overconfident agents punish for evaluations below } \\
\text { their own; underconfident reward for evaluations } \\
\text { above their own. No effect of money incentives }\end{array}$ \\
\hline $\begin{array}{l}\text { Berger, Harbring, } \\
\text { Sliwka (2013) }\end{array}$ & $\begin{array}{l}\text { Counting numbers } \\
\text { Germany }-256\end{array}$ & $\begin{array}{l}\text { Unrestricted rating } 1-5 / \\
\text { forced distribution in groups } \\
\text { of } 3 \text { workers }\end{array}$ & $\begin{array}{l}\text { Bonus associated } \\
\text { with rating }\end{array}$ & $\begin{array}{l}(+) \text { if forced distribution compared to standard } \\
\text { rating }(+6 \text { to } 12 \%) \text {. But }(-) \text { if sabotage is possible }\end{array}$ \\
\hline $\begin{array}{l}\text { Chew, Huang, Zhao } \\
\text { (2019) }\end{array}$ & $\begin{array}{l}\text { IQ test Singapore, } \\
\text { China } 701+445\end{array}$ & Absolute score & $\begin{array}{l}\text { Flat pay, piece } \\
\text { rate for recalls }\end{array}$ & $\begin{array}{l}\text { False memory of good news and amnesia of bad } \\
\text { news to increase confidence in future self }\end{array}$ \\
\hline $\begin{array}{l}\text { Ederer, Fehr } \\
\text { (2007) }\end{array}$ & $\begin{array}{l}\text { Abstract task } \\
\text { Switzerland - } 192\end{array}$ & $\begin{array}{l}\text { No feedback / true feedback / } \\
\text { biased feedback }\end{array}$ & $\begin{array}{l}\text { Dynamic } \\
\text { tournament }\end{array}$ & $\begin{array}{l}\text { (-) compared to truthful feedback. No feedback and } \\
\text { truthful feedback are better than biased feedback }\end{array}$ \\
\hline $\begin{array}{l}\text { Eriksson, Villeval } \\
(2012)\end{array}$ & $\begin{array}{l}\text { Gift-exchange } \\
\text { game France - } 180\end{array}$ & $\begin{array}{l}\text { Baseline/ Respect treatments } \\
\text { in } 3 \text { market conditions }\end{array}$ & Flat pay & $\begin{array}{l}(+) \text { Praise used as a coordination device to initiate } \\
\text { relational contracts; increases effort }\end{array}$ \\
\hline $\begin{array}{l}\text { Marchegiani,Reggia- } \\
\text { ni, Rizzolli (2016) }\end{array}$ & $\begin{array}{l}\text { Counting occur- } \\
\text { rence of } 1 \mathrm{~s} \text { in } \\
\text { tables }-84\end{array}$ & $\begin{array}{l}\text { Fair / Severe / Lenient } \\
\text { treatments; one-shot } \\
\text { within- subject design }\end{array}$ & Piece rate & $\begin{array}{l}\text { (-) after leniency and severity bias. Severity bias is } \\
\text { more detrimental to future effort provision than } \\
\text { leniency bias }\end{array}$ \\
\hline $\begin{array}{l}\text { Mohnen, Pokorny } \\
(2006)\end{array}$ & $\begin{array}{l}\text { Abstract effort } \\
\text { Germany }-172\end{array}$ & $\begin{array}{l}\text { Message on ability / no } \\
\text { message; repeated }\end{array}$ & Piece rate & $\begin{array}{l}(+) \text { after good news; }(-) \text { over time because of lies. } \\
\text { More deception with lower returns on effort. }\end{array}$ \\
\hline Rosaz (2012) & $\begin{array}{l}\text { Abstract effort } \\
\text { France }-112\end{array}$ & $\begin{array}{l}\text { Passive true feedback / active } \\
\text { feedback on ability }\end{array}$ & $\begin{array}{l}\text { Flat pay }+ \text { perfor- } \\
\text { mance bonus }\end{array}$ & $\begin{array}{l}(+) \text { in the treatment where feedback can be } \\
\text { manipulated }\end{array}$ \\
\hline $\begin{array}{l}\text { Rosaz, Villeval } \\
\text { (2012) }\end{array}$ & $\begin{array}{l}\text { Quiz } \\
\text { France - } 442 \\
\end{array}$ & $\begin{array}{l}\text { Feedback of rater to agent } \\
\text { and manager; one-shot }\end{array}$ & $\begin{array}{l}\text { Non-linear pay } \\
\text { scheme }\end{array}$ & $\begin{array}{l}\text { Frequent biased feedback: } 37 \% \text { selfish lies, } 53 \% \\
\text { Pareto white lies. Guilt aversion. }\end{array}$ \\
\hline $\begin{array}{l}\text { Schleicher, Bull, } \\
\text { Green (2009) }\end{array}$ & $\begin{array}{l}\text { Rating of students } \\
+ \text { employees } \\
\text { US }-300\end{array}$ & $\begin{array}{l}\text { Standard rating / } \\
\text { forced distribution }\end{array}$ & $\begin{array}{l}\text { Rating affects or } \\
\text { not grade / pay }\end{array}$ & $\begin{array}{l}\text { Increased difficulty and lower fairness of forced } \\
\text { rating for graders. Confirmed with managers }\end{array}$ \\
\hline $\begin{array}{l}\text { Sebald, Walzl } \\
\text { (2014) }\end{array}$ & $\begin{array}{l}\text { Clicking task } \\
\text { Denmark }-186\end{array}$ & $\begin{array}{l}\text { Subjective performance } \\
\text { rating in } 5 \text { categories }\end{array}$ & $\begin{array}{l}\text { Flat pay / } \\
\text { Incentive }\end{array}$ & $\begin{array}{l}\text { Reduction of the rater's payoff after a rating that } \\
\text { lies below agent's belief even when payoff is } \\
\text { independent. Unkindness judgment }\end{array}$ \\
\hline
\end{tabular}

Notes: Greyed cells correspond to studies in the domain of education. Numbers correspond to the number of participants. 
Table 3. Field studies on the effect of feedback on relative performance

\begin{tabular}{|c|c|c|c|c|}
\hline Studies & Context & feedback & Incentives & Main effects of feedback on performance \\
\hline $\begin{array}{l}\text { Ager, Bursztyn, } \\
\text { Voth (2016) }\end{array}$ & $\begin{array}{l}\text { Pilot fighters WWII } \\
\text { Germany - } 5081\end{array}$ & $\begin{array}{l}\text { Praise in armed force } \\
\text { bulletin }\end{array}$ & Flat pay? & $\begin{array}{l}(+) \text { higher effort, higher performance (only on high } \\
\text { skilled) but also more deaths (all) because of higher } \\
\text { risk-taking }\end{array}$ \\
\hline $\begin{array}{l}\text { Andrabi, Das, Ijaz } \\
\text { Khwaja (2017) }\end{array}$ & $\begin{array}{l}\text { Schools Pakistan }- \\
823 \text { schools }\end{array}$ & $\begin{array}{l}\text { Test scores and quintile } \\
\text { rank }+ \text { mean score schools }\end{array}$ & Individual & $\begin{array}{l}(+) \text { on test scores at the village level: }+42 \% \text {. } \\
\text { Decrease of school fees by } 17 \%\end{array}$ \\
\hline Ashraf (2018) & $\begin{array}{l}\text { Sweater factory } \\
\text { Bangladesh - } 366\end{array}$ & $\begin{array}{l}\text { No / Private / Public rank } \\
\text { feedback during } 10 \text { months }\end{array}$ & Piece rate & $\begin{array}{l}(+) 2.5 \% \text { if private rank higher than expected, }(-) \\
4 \% \text { otherwise: status concern. }-3 \% \text { for those } \\
\text { publicly ranked higher than friends: conformity }\end{array}$ \\
\hline $\begin{array}{l}\text { Bandiera, Barankai, } \\
\text { Rasul (2013) }\end{array}$ & 6 & $\begin{array}{l}\text { No / Weakly team } \\
\text { productivity rank }\end{array}$ & $\begin{array}{l}\text { Team p } \\
\text { tournam }\end{array}$ & $\begin{array}{l}(-)-14 \% \text {, due to teams }<40^{\text {th }} \text { perc. with feedback. } \\
(+)+24 \% \text { due to teams }>30^{\text {th }} \text { perc. with tournament. } \\
\text { Selection effects due to status concerns }\end{array}$ \\
\hline $\begin{array}{lr}\text { Banerjee, } & \text { Datta } \\
\text { Gupta, } & \text { Villeval } \\
(2018) & \\
\end{array}$ & $\begin{array}{l}\text { Memory +Ball tasks } \\
\text { India - } 360\end{array}$ & $\begin{array}{l}\text { Absolute and relative } \\
\text { feedback }\end{array}$ & $\begin{array}{l}\text { Piece rate vs. } \\
\text { tournament } \mathrm{w} / \mathrm{w} / \mathrm{o} \\
\text { quota }\end{array}$ & $\begin{array}{l}(+) \text { on competitiveness in the subsequent unrelated } \\
\text { task after good news in task } 1 . \text { (no) if bad news. } \\
\text { Motivated beliefs depending on group identity }\end{array}$ \\
\hline Bradler et al. (2016) & $\begin{array}{l}\text { Data-entry task; } \\
\text { Students Germany - } \\
363\end{array}$ & $\begin{array}{l}\text { Unexpected thank-you card } \\
\text { to none / all / the best / the } \\
\text { best } 3 \text { performers out of } 8\end{array}$ & Flat pay & $\begin{array}{l}(+)+5.2 \% \text { (all } \mathrm{p} \\
\text { (best } 1) . \text { Driven } 1 \\
\text { and reciprocity }\end{array}$ \\
\hline Burks et al. (2013) & $\begin{array}{l}\text { IQ + numeracy tests } \\
\text { US - } 1068\end{array}$ & $\begin{array}{l}\text { Possibility to o } \\
\text { relative perforr }\end{array}$ & Piece & $\begin{array}{l}\text { More confident subjects more likely to demand } \\
\text { feedback. No consistent with self-image but social } \\
\text { signaling }\end{array}$ \\
\hline $\begin{array}{l}\text { Buurman et al. } \\
(2020)\end{array}$ & \begin{tabular}{lc|} 
Teachers & in a \\
vocational & educ. \\
school Holland -322
\end{tabular} & $\begin{array}{lll}\text { No / Feedback from } \\
\text { students }\end{array}$ & Flat & $\begin{array}{l}\text { (no) effect overall on teachers' scores a year later. } \\
(+) \text { for teachers who receive a feedback lower than } \\
\text { their own evaluation. Only for females }\end{array}$ \\
\hline $\begin{array}{l}\text { Casas-Arce, Marti- } \\
\text { nez-Jerez (2009) }\end{array}$ & $\begin{array}{l}\text { Retailers in a LDC - } \\
1251\end{array}$ & Monthly interim rank & Sales & $\begin{array}{l}(+) 24 \% \text { overall. }(+) \text { on lower ranked retailers and } \\
(-) \text { on top ranked }\end{array}$ \\
\hline $\begin{array}{l}\text { Ashraf, Bandiera, } \\
\text { Lee (2014) }\end{array}$ & $\begin{array}{l}\text { Training program } \\
\text { Zambia - } 314\end{array}$ & $\begin{array}{l}\text { Absolute sc } \\
\text { name } 4 \text { best }\end{array}$ & $\begin{array}{l}\text { Award } \\
\text { / progr }\end{array}$ & $\begin{array}{l}\text { (-) with rank comparisons and } \\
\text { awards }\end{array}$ \\
\hline $\begin{array}{l}\text { Azmat, } \quad \text { Iriberri } \\
(2010)\end{array}$ & $\begin{array}{l}\text { High school Spain - } \\
1313\end{array}$ & $\begin{array}{l}\text { Own average grade }+ \text { class } \\
\text { average during a year }\end{array}$ & Individual grades & $\begin{array}{l}(+) \text { both after both good and bad news: }+5 \% \text { in } \\
\text { grades. Short termed. Competitive preferences }\end{array}$ \\
\hline Azmat et al. (2019) & $\begin{array}{l}\text { University Spain - } \\
977\end{array}$ & $\begin{array}{l}\text { Decile rank in grade every } \\
6 \text { months during } 3 \text { years }\end{array}$ & Individual grades & $\begin{array}{l}\text { (-) especially those who underestimated their rank. } \\
\text { Concern for rel. standing }+ \text { competitive preferences }\end{array}$ \\
\hline Barankay (2011) & $\begin{array}{l}\text { MTurk; analysis of } \\
\text { images }\end{array}$ & Performance rank & Piece rate & $\begin{array}{l}\text { (-) on probability to return }(-30 \%) \text { and on } \\
\text { productivity }(-22 \%)\end{array}$ \\
\hline Barankay (2012) & $\begin{array}{l}\text { Furniture salesmen, } \\
\text { US }\end{array}$ & $\begin{array}{l}\text { Withdrawing } \\
\text { feedback }\end{array}$ & ission-based & $\begin{array}{l}\text { (-) Demoralization after learning that they are less } \\
\text { well ranked than expected. }-20 \%\end{array}$ \\
\hline
\end{tabular}




\begin{tabular}{|c|c|c|c|c|}
\hline $\begin{array}{l}\text { Blader, Gartenberg, } \\
\text { Prat (2015) }\end{array}$ & $\begin{array}{l}\text { Transport company } \\
\text { US - } 5000\end{array}$ & $\begin{array}{l}\text { Absolute } v s \text {. public/private } \\
\text { relative performance }\end{array}$ & Seniority & $\begin{array}{l}(+) \text { only if the contract focuses on individual rather } \\
\text { than team performance }(+4.5 \% \text { vs. }-10.7 \%)\end{array}$ \\
\hline $\begin{array}{l}\text { Blanes i Vidal, } \\
\text { Nossol (2011) }\end{array}$ & $\begin{array}{l}\text { Wholesale and retail } \\
\text { firm Germany - } 63\end{array}$ & $\begin{array}{l}\text { Relative performance and } \\
\text { pay - Monthly }\end{array}$ & Pie & $\begin{array}{l}(+) \text { Long and durable increase in productivity } \\
(6.8 \%) \text {. Concern for relative standing }\end{array}$ \\
\hline $\begin{array}{l}\text { Brade, Himmler, } \\
\text { Jackle (2018) }\end{array}$ & $\begin{array}{l}1^{\text {st }} \text { year University } \\
\text { Germany } 812+797\end{array}$ & $\begin{array}{l}\text { Credits relative to median } \\
\text { and student on 80th } \\
\text { percentile }\end{array}$ & ing & $\begin{array}{l}(+) \text { when feedback is positive (with cue) and } \\
\text { students underestimate their relative performance. } \\
+0.2 \text { SD. Beliefs and selective processing }\end{array}$ \\
\hline Cabrera, Cid (2017) & deo - 1048 & $\begin{array}{l}\text { Ordinal ranking in GPA in } \\
\text { cohort, major and school }\end{array}$ & 1 grades & $\begin{array}{l}(-) \text { on females' scores, exams taken and } \\
\text { satisfaction. Better self-placement }\end{array}$ \\
\hline $\begin{array}{l}\text { Casas-Arce, Marti- } \\
\text { nez-Jerez (2009) }\end{array}$ & $\begin{array}{l}\text { Retailers in a LDC - } \\
1251\end{array}$ & Monthly interim rank & $\begin{array}{l}\text { Dynamic sales } \\
\text { tournaments }\end{array}$ & $\begin{array}{l}(+) 24 \% \text { overall. }(+) \text { on lower ranked retailers and } \\
(-) \text { on top ranked }\end{array}$ \\
\hline $\begin{array}{ll}\text { Celik } & \text { Katreniak } \\
(2018) & \\
\end{array}$ & $\begin{array}{l}52 \text { rural schools } \\
\text { Uganda }-7150\end{array}$ & $\begin{array}{l}\text { up mates }+ \\
\text { s classes } \\
\end{array}$ & $\begin{array}{l}\text { Money/reputation } \\
\text { for } 15 \% \text { best }\end{array}$ & $\begin{array}{l}(+) \text { when feedback and financial rewards are } \\
\text { combined. }(+) \text { stress. Gender differences }\end{array}$ \\
\hline Cotofan (2019) & $\begin{array}{l}\text { Teachers second. } \\
\text { Sc. Romania - } 973\end{array}$ & $\begin{array}{l}\text { No / Unexpected } \\
\text { Repeated public praise }\end{array}$ & $\begin{array}{l}\text { Flat pay }+ \text { public } \\
\text { praise }\end{array}$ & $\begin{array}{l}\text { ed teachers, } \\
\text { ling }\end{array}$ \\
\hline $\begin{array}{l}\text { Delfgaauw et al. } \\
\text { (2013) }\end{array}$ & $\begin{array}{lr}\text { Retail } & \text { chain } \\
\text { Netherlands } & -128 \\
\text { stores } & \\
\end{array}$ & ig of stores & & $\begin{array}{l}\text { ployees } \\
\text { rences }\end{array}$ \\
\hline $\begin{array}{l}\text { Dobrescu et al. } \\
(2019)\end{array}$ & $\begin{array}{l}\text { ty students } \\
\text { ask - } 1101\end{array}$ & $\begin{array}{l}\text { Continuous and private } \\
\text { feedback on rank }\end{array}$ & & $\begin{array}{l}\mathrm{g} \text { on mean grade in } \\
\end{array}$ \\
\hline $\begin{array}{l}\text { Fershtman and } \\
\text { Gneezy (2011) }\end{array}$ & $\begin{array}{l}\text { Race with } 10^{\text {th-}} \text { grade } \\
\text { high shool students } \\
\text { Israel - } 430\end{array}$ & No / Continuous feedback & $\begin{array}{l}\text { nent } \\
\text { l1/Medium/ } \\
\text { izes }\end{array}$ & $\begin{array}{l}\text { (-) due to more quitting with high prize and } \\
\text { continuous feedback. No quitting with no or low } \\
\text { prizes }\end{array}$ \\
\hline $\mathrm{Fi}$ & $\begin{array}{l}\text { y school } \\
-352\end{array}$ & in rank. & Ind & r low \\
\hline $\begin{array}{l}\text { Genakos, Pagliero } \\
\text { (2012) }\end{array}$ & $\begin{array}{l}\text { ht-lifting } \\
\text { etition }\end{array}$ & Inter & ent & $\begin{array}{l}\text { (+) Inverted U-shape link between interim rank } \\
\text { and risk-taking. Higher } \mathrm{p} \text { (success) if lower rank: } \\
\text { choking under pressure }\end{array}$ \\
\hline $\begin{array}{l}\text { Goulas, M } \\
\text { nomou }(201\end{array}$ & $\begin{array}{l}\text { Sec } \\
\text { Gre }\end{array}$ & $\begin{array}{l}\text { School and national rank, } \\
\text { public }\end{array}$ & Ind & $\begin{array}{l}\text { ntile. } \\
\text { lity }\end{array}$ \\
\hline Haenni (2019) & $\begin{array}{l}\text { Tennis players. } \\
\text { Switzerland } 44799\end{array}$ & $\begin{array}{l}\text { National ranking } \\
\text { feedback competition }\end{array}$ & $\begin{array}{l}\text { Amateur } \\
\text { tournament }\end{array}$ & $\begin{array}{l}(-) \text { for losers, } \\
\text { Loss in referen }\end{array}$ \\
\hline $\begin{array}{l}\text { Hermes et al. } \\
\text { (2019) }\end{array}$ & $\begin{array}{l}\text { Primary schools } \\
\text { Germany - } 378\end{array}$ & $\begin{array}{l}\text { Absolute } v s \text {. class ranking } \\
\text { feedback on improvement }\end{array}$ & $\begin{array}{l}\text { Points based on } \\
\text { improvement }\end{array}$ & $\begin{array}{l}(+) \text { on low achievers, (no) on high achievers. } \\
\text { Stronger for females. }(+) \text { motivation, self-efficacy }\end{array}$ \\
\hline $\begin{array}{l}\text { Huffman,Raymond, } \\
\text { Shvets (2019) }\end{array}$ & Store managers & $\begin{array}{l}\text { Public signals } \\
\text { performance }\end{array}$ & Tournament & $\begin{array}{l}\text { Skewed memory errors by poor performers. } \\
\text { Correlated with overconfidence about future score }\end{array}$ \\
\hline
\end{tabular}




\begin{tabular}{|l|l|l|l|l|}
\hline $\begin{array}{l}\text { Jalava, Joensen, } \\
\text { Pellas (2015) }\end{array}$ & $\begin{array}{l}6^{\text {th }} \text { grade in 17 } \\
\text { schools Sweden - } \\
1045\end{array}$ & $\begin{array}{l}\text { Grades A-F / Grade A if top } \\
\text { / Certificate A-B / Prize } \\
\text { for top 3 }\end{array}$ & $\begin{array}{l}\text { Symbolic award in } \\
\text { one treatment }\end{array}$ & $\begin{array}{l}(+) \text { on high achievers with rank grading and } \\
\text { symbols; }(+) \text { on two middle quartiles; }(\text { no) on low } \\
\text { achievers }\end{array}$ \\
\hline $\begin{array}{l}\text { Kajitani, Morimoto, } \\
\text { Suzuki (2019) }\end{array}$ & $\begin{array}{l}1^{\text {st }} \text { year University } \\
\text { Japan - 255 }\end{array}$ & $\begin{array}{l}\text { Score + rank in mid-term } \\
\text { exam }\end{array}$ & $\begin{array}{l}\text { Relative grading } \\
\text { (tournament) }\end{array}$ & $\begin{array}{l}(+) \text { on exam score on average, due to improvement } \\
\text { of low-performing students }\end{array}$ \\
\hline $\begin{array}{l}\text { Kosfeld,Neckerman } \\
(2011)\end{array}$ & $\begin{array}{l}\text { Data-entry job } \\
\text { Switzerland - 184 }\end{array}$ & $\begin{array}{l}\text { Award assigned to the best } \\
\text { two performers }\end{array}$ & $\begin{array}{l}\text { Flat pay } \\
(+)+12 \% \text { on average performance; stronger effect } \\
\text { on more productive workers. Status recognition }\end{array}$ \\
\hline $\begin{array}{l}\text { Lount, Wilk (2014) }) \\
\text { Call center with } \\
\text { teams of 2 to 4 - 737 }\end{array}$ & $\begin{array}{l}\text { Public posting of weekly } \\
\text { individual performance }\end{array}$ & $\begin{array}{l}\text { ? } \\
\text { employees work alone and eliminates social loafing }\end{array}$ \\
\hline $\begin{array}{l}\text { Tran, Zeckhauser } \\
(2012)\end{array}$ & $\begin{array}{l}\text { University Vietnam } \\
-124\end{array}$ & $\begin{array}{l}\text { Private/public information } \\
\text { on rank - biweekly tests }\end{array}$ & $\begin{array}{l}\text { Success in the } \\
\text { TOEIC test }\end{array}$ & $\begin{array}{l}(+) \text { score 64\% } \text { (91\%) higher in Private }(\text { Public) } \\
\text { compared to Baseline. Competitive preferences }\end{array}$ \\
\hline
\end{tabular}

Notes: Greyed cells correspond to studies in the domain of education. Numbers correspond to the number of participants. SD for standard deviation.

Table 4. Laboratory and online controlled experiments on the effects of feedback on relative performance

\begin{tabular}{|c|c|c|c|c|}
\hline Studies & Context & Nature feedback & Incentives & Main effects of feedback on performance \\
\hline $\begin{array}{l}\text { Azmat, Iriberri } \\
(2016)\end{array}$ & $\begin{array}{l}\text { Real effort task } \\
\text { University Spain - } \\
160\end{array}$ & $\begin{array}{l}\text { Own performance and group } \\
\text { average }\end{array}$ & $\begin{array}{l}\text { Piece rate, flat } \\
\text { pay }\end{array}$ & $\begin{array}{l}(+) \text { under piece rate only, for both those above or } \\
\text { below the average. }+17 \% \text {. Change in well-being }\end{array}$ \\
\hline $\begin{array}{l}\text { Buser, Gerhards, } \\
\text { van der Weele } \\
(2018)\end{array}$ & $\begin{array}{l}3 \text { cognitive tasks } \\
\text { Denmark - } 297\end{array}$ & $\begin{array}{l}\text { Noisy signals about } \\
\text { likelihood of having scored } \\
\text { in the top half in groups of } 8\end{array}$ & $\begin{array}{l}\text { Piece rate } / \\
\text { Tournament }\end{array}$ & $\begin{array}{l}\text { Conservatism bias that is correlated across tasks } \\
\text { (personal trait). No asymmetric updating }\end{array}$ \\
\hline Cadsby et al. (2019) & $\begin{array}{l}\text { Adding numbers } \\
\text { Students / workers } \\
\text { China }-220+340 \\
\end{array}$ & $\begin{array}{l}\text { No / Public/ Private rank } \\
\text { feedback }\end{array}$ & $\begin{array}{l}\text { Flat pay / Rank- } \\
\text { based pay }\end{array}$ & $\begin{array}{l}(+) \text { for both samples under fixed pay. No } \\
\text { difference private/public. Risk aversion reduces } \\
\text { the effect of feedback }\end{array}$ \\
\hline $\begin{array}{l}\text { Charness, Masclet, } \\
\text { Villeval (2013) }\end{array}$ & $\begin{array}{l}\text { Decoding task } \\
\text { France }\end{array}$ & $\begin{array}{l}\text { Distribution of scores in } \\
\text { triplets }\end{array}$ & Flat pay & $\begin{array}{l}\text { (no) on score and }(+) \text { on sabotage and doping. } \\
\text { Competitive preferences }\end{array}$ \\
\hline $\begin{array}{l}\text { Drouvelis, Paiardini } \\
\text { (2019) }\end{array}$ & $\begin{array}{l}\text { Encryption task } \\
\text { UK - } 248\end{array}$ & $\begin{array}{l}\text { No / Vague / Precise rank } \\
\text { feedback }\end{array}$ & Flat pay & $\begin{array}{l}(+) \text { at all ranks if Precise feedback. If Vague } \\
\text { feedback, }(+) \text { only on low ranks compared to No }\end{array}$ \\
\hline Eil and Rao (2011) & $\begin{array}{l}\text { IQ test or attract- } \\
\text { tiveness US - } 142\end{array}$ & $\begin{array}{l}\text { Truthful pairwise compa- } \\
\text { rison of rank in groups of } 10\end{array}$ & Piece rate for IQ & $\begin{array}{l}\text { Bayesian updating after good news but } \\
\text { discounting of the strength of bad news }\end{array}$ \\
\hline $\begin{array}{l}\text { Eriksson, Poulsen, } \\
\text { Villeval (2009) }\end{array}$ & $\begin{array}{l}\text { Adding numbers; } \\
\text { pairs; France }\end{array}$ & $\begin{array}{l}\text { Continuous vs. interim } \\
\text { feedback } v s \text {. no feedback }\end{array}$ & $\begin{array}{l}\text { Piece rate } v s \\
\text { tournament }\end{array}$ & $\begin{array}{l}\text { (no) on score but (-) on quality of work. No quitting } \\
\text { when performance gap increases. Image concerns }\end{array}$ \\
\hline Ertac et al. (2016) & $\begin{array}{l}\text { Addition and } \\
\text { verbal tasks } \\
\text { Turkey - } 132\end{array}$ & $\begin{array}{l}\text { Private / Public; Truthful/ } \\
\text { Verifiable / Unverifiable. } 1\end{array}$ & $\begin{array}{l}\text { Non-linear } \\
\text { target-based pay } \\
\text { for agents }\end{array}$ & $\begin{array}{l}(+) \text { Inducing higher beliefs increases performance } \\
\text { but interim feedback is not efficient }\end{array}$ \\
\hline
\end{tabular}




\begin{tabular}{|c|c|c|c|c|}
\hline & & $\begin{array}{l}\text { principal, } 2 \text { agents; efforts } \\
\text { are complement }\end{array}$ & & \\
\hline Ertac et al. (2019) & $\begin{array}{l}\text { Abstract effort in } \\
\text { games Turkey - } \\
165\end{array}$ & $\begin{array}{l}\text { No/Private / Public feedback } \\
\text { on ability in teams with } 1 \\
\text { principal and } 2 \text { agents }\end{array}$ & $\begin{array}{l}\text { Weak link / Best } \\
\text { Shot games }\end{array}$ & $\begin{array}{l}(+) \text { with feedback in Best Shot game except if all } \\
\text { low performers. (-) with feedback in Weak Link } \\
\text { game except if all high performers }\end{array}$ \\
\hline Ertac (2011) & $\begin{array}{l}\text { Addition + verbal } \\
\text { tasks US - } 230\end{array}$ & $\begin{array}{l}\text { Top - non top / Bottom - non } \\
\text { bottom }\end{array}$ & Piece rate & $\begin{array}{l}\text { Pessimistic updating except for the self-confident } \\
\text { subjects }\end{array}$ \\
\hline $\begin{array}{l}\text { Freeman, Gelber } \\
(2010)\end{array}$ & $\begin{array}{l}\text { Solving mazes in } \\
\text { groups of } 6 \\
\text { US - } 468 \\
\end{array}$ & $\begin{array}{l}\text { Full information / no } \\
\text { information on ability }\end{array}$ & $\begin{array}{l}\text { Single/multiple / } \\
\text { equal prize } \\
\text { tournament }\end{array}$ & $\begin{array}{l}(+) \text { under equal and multiple prizes. Info increases } \\
\text { the gap between multiple prizes and single prize }\end{array}$ \\
\hline $\begin{array}{l}\text { Gürtler, Harbring } \\
(2010)\end{array}$ & $\begin{array}{l}\text { Abstract effort } \\
\text { Germany - } 180 \\
\end{array}$ & $\begin{array}{l}\text { Principal releases or conceals } \\
\text { interim feedback to agents }\end{array}$ & Tournament & $\begin{array}{l}\text { (-) when interim information reveals a larger } \\
\text { ability gap. Effort }>\text { than predicted if no feedback }\end{array}$ \\
\hline $\begin{array}{l}\text { Hannan, Krishnan, } \\
\text { Newman (2008) }\end{array}$ & $\begin{array}{l}\text { Production game } \\
\text { US - } 131\end{array}$ & $\begin{array}{l}\text { No vs. coarse vs. precise } \\
\text { relative performance }\end{array}$ & $\begin{array}{l}\text { Piece rate } v s . \\
\text { tournament }\end{array}$ & $\begin{array}{l}(+) \text { under piece rate; in tournament }(-) \text { if feedback } \\
\text { is precise and (no) if coarse. Ineffective strategies }\end{array}$ \\
\hline Hannan et al. (2013) & $\begin{array}{l}\text { Verbal and math } \\
\text { tasks. Allocation } \\
\text { of time to tasks }\end{array}$ & $\begin{array}{l}\text { No vs. Public vs. Private } \\
\text { performance rank feedback } \\
\text { in groups of } 5\end{array}$ & Effort input pay & $\begin{array}{l}(+) \text { total pb solved. }(-) \text { overall because of distortion } \\
\text { if feedback is public }\end{array}$ \\
\hline Heursen (2019) & $\begin{array}{lr}\text { General } \\
\text { knowledge quiz } \\
\text { Switzerland }-282 \\
\end{array}$ & $\begin{array}{l}\text { Absolute } v s . \quad \text { rank } \\
\text { performance in groups of } 3 ; \\
\text { private } v s . \text { public }\end{array}$ & $\begin{array}{l}\text { Piece rate } v s . \\
\text { relative pay }\end{array}$ & $\begin{array}{l}(+) \text { competitive mindset. (no) effect on subsequent } \\
\text { willingness to help, regardless of condition }\end{array}$ \\
\hline $\begin{array}{l}\text { Huang, } \quad \text { Murad } \\
(2019)\end{array}$ & $\begin{array}{l}\text { Visual perception } \\
+ \text { math tasks } \\
\text { UK }-168 \\
\end{array}$ & $\begin{array}{l}\text { No / Relative performance } \\
\text { feedback (top } 2 / \text { bottom } 2 \text { ) in } \\
\text { groups of } 4\end{array}$ & Piece rate & $\begin{array}{l}(+) \text { on competitiveness across unrelated tasks } \\
\text { driven by beliefs and tastes }\end{array}$ \\
\hline $\begin{array}{l}\text { Gerhards, Siemer } \\
(2012)\end{array}$ & $\begin{array}{l}\text { Slider task }+ \text { IQ } \\
\text { Germany }-279\end{array}$ & $\begin{array}{l}\text { No / Private / Public interim } \\
\text { feedback on being the best in } \\
\text { groups of } 5\end{array}$ & $\begin{array}{l}\text { Flat pay }+ \\
\text { Symbolic award } \\
\text { in Public }\end{array}$ & $\begin{array}{l}(+) \text { with Private feedback compared to No } \\
\text { feedback. No additional effect of public display }\end{array}$ \\
\hline Gill, Prowse (2012) & $\begin{array}{l}\text { Slider task. } 2 \\
\text { players UK - } 120\end{array}$ & $\begin{array}{l}\text { Information on } 1^{\text {st }} \text { mover's } \\
\text { effort in sequential moves }\end{array}$ & $\begin{array}{l}\text { Tournament } \\
\text { with linear } \\
\text { winning proba } \\
\end{array}$ & $\begin{array}{l}\text { (-) Disappointment aversion compared to a } \\
\text { dynamic reference point }\end{array}$ \\
\hline Gill et al. (2018) & $\begin{array}{l}\text { Verbal+numerical } \\
\text { tasks UK - } 306\end{array}$ & $\begin{array}{l}\text { No feedback / rank-order } \\
\text { feedback }\end{array}$ & Flat pay & $\begin{array}{l}(+)+20 \% \text { on average. U-shaped rank response } \\
\text { function }\end{array}$ \\
\hline $\begin{array}{l}\text { Kuhnen, Tymula } \\
\text { (2012) }\end{array}$ & $\begin{array}{l}\text { Multiplications - } \\
\text { US - } 54\end{array}$ & $\begin{array}{l}\text { No /Maybe/Sure private rank } \\
\text { feedback in groups } 6 \text { to } 9\end{array}$ & Flat pay & $\begin{array}{l}(+) 12 \% \text { higher in Maybe compared to No ex ante. } \\
\text { Ex Post, ratcheting due to top performers } \\
\text { competing to keep rank. Self-esteem }\end{array}$ \\
\hline $\begin{array}{l}\text { Ludwig, } \quad \text { Lünser } \\
(2012)\end{array}$ & $\begin{array}{l}\text { Abstract effort } \\
\text { Germany - } 72\end{array}$ & $\begin{array}{l}\text { Info / No Info on effort levels } \\
\text { after the first stage }\end{array}$ & $\begin{array}{l}\text { 2-stage 2-player } \\
\text { tournament }\end{array}$ & $\begin{array}{l}\text { (no) overall but (-) on welfare. No difference when } \\
\text { information is free or costly. Status concerns }\end{array}$ \\
\hline
\end{tabular}




\begin{tabular}{|c|c|c|c|c|}
\hline $\begin{array}{l}\text { Mago, Samek, } \\
\text { Sheremata (2016) }\end{array}$ & $\begin{array}{l}\text { Lottery contests in } \\
\text { groups of } 4 \\
\text { US - } 240\end{array}$ & $\begin{array}{l}\text { No / Ex post feedback on } \\
\text { each contestant's effort }\end{array}$ & Contest & $\begin{array}{l}\text { (no) overall but information decreases between- } \\
\text { subject heterogeneity of effort }((+) \text { below median } \\
\text { and }(-) \text { below median). Regret }\end{array}$ \\
\hline Möbius et al. (2011) & IQ test US - 656 & $\begin{array}{l}\text { Binary signal on top or } \\
\text { bottom half }(75 \% \text { accurate })\end{array}$ & Piece rate & $\begin{array}{l}\text { Conservative and asymmetric updating: over- } \\
\text { weighting positive feedback relative to negative }\end{array}$ \\
\hline $\begin{array}{l}\text { Newman, Tafkov } \\
\text { (2014) }\end{array}$ & $\begin{array}{l}\text { Production game } \\
\text { in groups of } 5 \\
\text { US - } 80\end{array}$ & $\begin{array}{l}\text { No / Ex post rank feedback in } \\
4 \text { of } 12 \text { trials }\end{array}$ & $\begin{array}{l}\text { Tournament w/ } \\
\text { or w/o sanction }\end{array}$ & $\begin{array}{l}(-) \text { if only winner prize; }(+) \text { if winner prize }+ \\
\text { sanction of lowest performer }\end{array}$ \\
\hline $\begin{array}{l}\text { Rose, Windschitl } \\
\text { (2008) }\end{array}$ & $\begin{array}{l}\text { Trivia competition } \\
\text { US }-179\end{array}$ & $\begin{array}{l}\text { Own feedback / Repeat } \\
\text { win/loss feedback in pairs }\end{array}$ & $\begin{array}{l}\text { Hypothetical } \\
\text { gains }\end{array}$ & $\begin{array}{l}\text { Less egocentric weighting and optimism bias } \\
\text { across rounds. Does not generalize to new contexts }\end{array}$ \\
\hline So et al. (2016) & $\begin{array}{l}\text { Multiple cue } \\
\text { learning task, New } \\
\text { Zealand - } 274\end{array}$ & $\begin{array}{l}\text { No / Rank information in } \\
\text { pairs }\end{array}$ & $\begin{array}{l}\text { Piece-rate / } \\
\text { tournament }\end{array}$ & (no) effect on productivity or learning \\
\hline Tajkov (2013) & $\begin{array}{l}\text { Multiplication } \\
\text { problems US - } 120\end{array}$ & $\begin{array}{l}\text { Absolute / Private / Public } \\
\text { rank feedback }\end{array}$ & $\begin{array}{l}\text { Flat pay / Piece } \\
\text { rate }\end{array}$ & $\begin{array}{l}(+) \text { Stronger effect when feedback is public and } \\
\text { under performance pay. Social comparisons }\end{array}$ \\
\hline $\begin{array}{l}\text { Wozniak,Harbaugh, } \\
\text { Mayr (2014) }\end{array}$ & $\begin{array}{l}\text { Math }+ \text { verbal } \\
\text { tasks US - } 219\end{array}$ & $\begin{array}{l}\text { Relative performance } \\
\text { feedback }\end{array}$ & $\begin{array}{l}\text { Piece-rate / } \\
\text { tournament }\end{array}$ & $\begin{array}{l}\begin{array}{l}\text { Feedback eliminates the gender gap in } \\
\text { competitiveness }\end{array} \\
\end{array}$ \\
\hline $\begin{array}{l}\text { Zimmermann } \\
(2019)\end{array}$ & $\begin{array}{l}\text { IQ test } \\
\text { Germany - } 339\end{array}$ & $\begin{array}{l}\text { No / Rank feedback in a sub- } \\
\text { group of } 3\end{array}$ & Flat pay & $\begin{array}{l}\text { Asymmetric recall of feedback: the memory of bad } \\
\text { news is suppressed after a month }\end{array}$ \\
\hline
\end{tabular}

Notes: Numbers correspond to the number of participants. SD for standard deviation.

Table 5. Field studies on peer effects at work

\begin{tabular}{|c|c|c|c|c|}
\hline Studies & Context & Information on peers & Incentives & Peer effects on performance \\
\hline $\begin{array}{l}\text { Amodio, Martinez- } \\
\text { Carrasco (2014) }\end{array}$ & $\begin{array}{l}\text { Poultry farm } \\
\text { Peru - 100/day }\end{array}$ & $\begin{array}{l}\text { Assignment of various } \\
\text { quality inputs to workers. } \\
\text { Observability }\end{array}$ & $\begin{array}{l}\text { Flat wage }+ \text { piece } \\
\text { rate bonus above } \\
\text { a threshold }\end{array}$ & $\begin{array}{l}\text { (-) A one SD increase in peers' average output } \\
\text { decreases a given worker's output by } 1 / 3 \text { of a SD. } \\
\text { Reduces risk of firing and encourages free riding }\end{array}$ \\
\hline $\begin{array}{l}\text { Arcidiacono, } \\
\text { Kinsler, } \\
(2017)\end{array}$ & $\begin{array}{l}\text { Professional } \\
\text { Basketball } \\
\text { US - } 656\end{array}$ & $\begin{array}{l}\text { Teamwork with productive } \\
\text { externalities }\end{array}$ & $\begin{array}{l}\text { Competitive team } \\
\text { bonus }\end{array}$ & $\begin{array}{l}\text { (+) Productivity spillovers come from the ability of } \\
\text { some players to help teammates increase their } \\
\text { productivity. But little weight in compensation }\end{array}$ \\
\hline Arpey (2014) & $\begin{array}{l}\text { Weaving } \\
\text { company } \\
\text { China }-326 \\
\end{array}$ & Observability of co-workers & $\begin{array}{l}\text { Competitive team } \\
\text { bonus }\end{array}$ & $\begin{array}{l}\text { (no) overall. But decrease in free riding of low } \\
\text { productivity workers after introduction of a high } \\
\text { ability peer. Contagious enthusiasm to earn bonus }\end{array}$ \\
\hline $\begin{array}{l}\text { Babcock et al. } \\
(2015)\end{array}$ & $\begin{array}{l}\text { Pay for studying } \\
\text { or for exercise } \\
\text { US - } 1093\end{array}$ & Payoff externalities & $\begin{array}{l}\text { No / Individual / } \\
\text { Team incentives }\end{array}$ & $\begin{array}{l}(+) \text { Team treatment increases productivity by } 9 \text { to } \\
17 \% \text {. Social pressure and willingness to not let the } \\
\text { team down }\end{array}$ \\
\hline
\end{tabular}




\begin{tabular}{|c|c|c|c|c|}
\hline $\begin{array}{l}\text { Bandiera, Barankai, } \\
\text { Rasul (2005) }\end{array}$ & $\begin{array}{l}\text { Fruit producer } \\
\text { UK - } 142\end{array}$ & $\begin{array}{l}\text { Observation of co-workers } \\
\text { who are friends or not. No } \\
\text { productive externalities }\end{array}$ & $\begin{array}{l}\text { Piece rate / } \\
\text { relative } \\
\text { incentives }\end{array}$ & $\begin{array}{l}-50 \% \text { under relative incentives: internalization of } \\
\text { negative externality on others. Social pressure } \\
\text { among friends (and not altruism) }\end{array}$ \\
\hline $\begin{array}{l}\text { Bandiera, Barankai, } \\
\text { Rasul (2010) }\end{array}$ & $\begin{array}{l}\text { Fruit producer } \\
\text { UK - } 289\end{array}$ & $\begin{array}{l}\text { Observation of co-workers } \\
\text { who are friends or not. No } \\
\text { productive externalities }\end{array}$ & $\begin{array}{l}\text { Individual piece- } \\
\text { rate }\end{array}$ & $\begin{array}{l}(+) \text { overall. }+10 \% \text { when working alongside a more } \\
\text { able friend; }-10 \% \text { when working alongside a less } \\
\text { able friend. Conformity to a social norm }\end{array}$ \\
\hline $\begin{array}{l}\text { Bradley, Green, } \\
\text { Leeves (2007) }\end{array}$ & $\begin{array}{l}\text { Teachers primary } \\
\& \text { second. schools } \\
\text { Australia }-25504\end{array}$ & Observability of absenteeism & Flat pay & $\begin{array}{l}\text { (-) Absenteeism increases by one day when peers' } \\
\text { absenteeism is at least } 12 \text { days. Social norm }\end{array}$ \\
\hline $\begin{array}{l}\text { Chan, Li, Pierce } \\
(2014)\end{array}$ & $\begin{array}{l}\text { Cosmetic counters } \\
\text { in a department } \\
\text { store China - } 61\end{array}$ & $\begin{array}{l}\text { Observability of employees } \\
\text { within/between counters. No } \\
\text { productive externalities }\end{array}$ & $\begin{array}{l}\text { Team/Individual- } \\
\text { based sales } \\
\text { commissions }\end{array}$ & $\begin{array}{l}(+) \text { Compensation mode affects help and } \\
\text { competition within and between firms. } \\
\text { Heterogeneity in ability increases (decreases) firm } \\
\text { performance in team (ind.) compensation }\end{array}$ \\
\hline Chan (2016) & $\begin{array}{l}\text { Physicians in an } \\
\text { emergency dept } \\
\text { US - } 92\end{array}$ & $\begin{array}{l}\text { Observability of another } \\
\text { physician in the team; } \\
\text { substitutability of effort }\end{array}$ & Flat pay & $\begin{array}{l}(+) \text { Less foot-dragging under nurse-managed } \\
\text { system when another physician is present. Mutual } \\
\text { monitoring as peer observe true workload }\end{array}$ \\
\hline $\begin{array}{l}\text { Gould, Winter } \\
\text { (2011) }\end{array}$ & $\begin{array}{l}\text { Baseball players } \\
\text { US - >20000 }\end{array}$ & $\begin{array}{l}\text { Observability, with } \\
\text { complementarity / substitu- } \\
\text { tability of effort }\end{array}$ & Team incentives & $\begin{array}{l}(+) \text { if efforts are complements, (-) if efforts are } \\
\text { substitutes. Pure income maximization }\end{array}$ \\
\hline $\begin{array}{l}\text { de Grip, } \\
\text { Sauermann (2012) }\end{array}$ & $\begin{array}{l}\text { Training program } \\
\text { in a call center } \\
\text { Holland }-74\end{array}$ & $\begin{array}{l}\text { Observability of co-workers } \\
\text { in work teams; productive } \\
\text { complementarity }\end{array}$ & $\begin{array}{l}\text { Flat pay }+ \text { annual } \\
\text { bonus }\end{array}$ & $\begin{array}{l}(+) \text { A } 10 \% \text { increase in share of trained agents } \\
\text { increases by } 0.5 \% \text { untreated agent's productivity. } \\
\text { Knowledge spillovers }\end{array}$ \\
\hline $\begin{array}{l}\text { Guryan, Kroft, } \\
\text { Notowidigdo(2009) }\end{array}$ & $\begin{array}{l}\text { Professional golf } \\
\text { players worldwide } \\
-17492 \text { obs. }\end{array}$ & No productive externalities & $\begin{array}{l}\text { Tournament with } \\
\text { convex pay } \\
\text { structure }\end{array}$ & $\begin{array}{l}\text { (no) ability- or performance-based peer effects } \\
\text { (neither learning, nor motivation) }\end{array}$ \\
\hline $\begin{array}{l}\text { Ichino, Maggi } \\
(2000)\end{array}$ & Bank Italy - 28642 & $\begin{array}{l}\text { Between-region movers and } \\
\text { stayers. No productive } \\
\text { externalities }\end{array}$ & $?$ & $\begin{array}{l}\text { (+) Absenteeism increases with co-workers' } \\
\text { average shirking. Less peer/manager monitoring, } \\
\text { less guilt }\end{array}$ \\
\hline $\begin{array}{l}\text { Kane, Ransbotham, } \\
\text { Boynton (2015) }\end{array}$ & $\begin{array}{l}\text { Knowledge wor- } \\
\text { kers, service com- } \\
\text { pany US - } 248\end{array}$ & $\begin{array}{l}\text { Communication through } \\
\text { email; productive } \\
\text { complementarity }\end{array}$ & Flat pay & $\begin{array}{l}(+) \text { when peer is high performing and (no) with } \\
\text { low performer. High performers benefit more } \\
\text { from peer effects. Social learning and reciprocity }\end{array}$ \\
\hline Kato, Shu (2008) & $\begin{array}{l}\text { Textile company } \\
\text { China - } 297\end{array}$ & Social interactions after work & $\begin{array}{l}\text { Individual } \\
\text { performance pay }\end{array}$ & $\begin{array}{l}\text { (+) Knowledge spillovers from high- to low- } \\
\text { skilled workers, not from low to high. Significant } \\
\text { only when rural weavers work with in-groups }\end{array}$ \\
\hline $\begin{array}{l}\text { Kaur, Kremer, } \\
\text { Mullainathan(2010) }\end{array}$ & $\begin{array}{l}\text { Data entry jobs } \\
\text { India - ? }\end{array}$ & $\begin{array}{l}\text { Observability of co-workers; } \\
\text { no productive externalities }\end{array}$ & Piece rate & $\begin{array}{l}(+) \text { A peer with above average prody increases } \\
\text { own prody by } 5 \% \text { through increased working time } \\
\text { and reduces demand for commitment contracts }\end{array}$ \\
\hline
\end{tabular}




\begin{tabular}{|l|l|l|l|l|}
\hline $\begin{array}{l}\text { Lindquist, } \\
\text { Sauermann, Zenou } \\
(2015)\end{array}$ & $\begin{array}{l}\text { Training program } \\
\text { in a call center } \\
\text { Holland }-425\end{array}$ & $\begin{array}{l}\text { Observability of co-workers } \\
\text { in teams; productive } \\
\text { complementarity }\end{array}$ & $\begin{array}{l}\text { Flat pay }+ \text { annual } \\
\text { bonus }\end{array}$ & $\begin{array}{l}(+) 1.7 \% \text { for a 10\% increase in co-worker network } \\
\text { productivity: peer pressure. }(+) 0.7 \% \text { when adding } \\
\text { one trained co-worker: knowledge spillovers }\end{array}$ \\
\hline Mas, Moretti (2009) & $\begin{array}{l}\text { Cashiers in } \\
\text { a grocery store US } \\
-394\end{array}$ & $\begin{array}{l}\text { Observability in lines; } \\
\text { substitutable effort }\end{array}$ & $\begin{array}{l}\text { Flat pay } \\
(+) \text { 1.5\% for a 10\% increase in co-worker's } \\
\text { productivity; only if the more productive cashier is } \\
\text { behind. Social pressure }\end{array}$ \\
\hline $\begin{array}{l}\text { Steinbach, Tatsi } \\
(2018)\end{array}$ & $\begin{array}{l}\text { Warehouse agents } \\
\text { in teams Germany } \\
-320\end{array}$ & $\begin{array}{l}\text { Observability in teams; } \\
\text { substitutable effort }\end{array}$ & $\begin{array}{l}(+) 10 \% \text { increase in peers' contemporaneous prod. } \\
\text { increases own by 5.5\%; }(-) 10 \% \text { increase in their } \\
\text { permanent prod. decreases it by 2.2\% } \\
\text { (no) no localized peer effects on publications, even } \\
\text { after the loss of high-quality peers }\end{array}$ \\
\hline Waldinger (2012) & $\begin{array}{l}\text { Scientists 1925-38 } \\
\text { Germany - 854 }\end{array}$ & $\begin{array}{l}\text { Dismissal of scientists in } \\
\text { research departments }\end{array}$ & Flat pay & \\
\hline
\end{tabular}

Notes: Numbers correspond to the number of participants. SD for standard deviation.

Table 6. Laboratory studies on peer effects at work

\begin{tabular}{|c|c|c|c|c|}
\hline Studies & Context & Information on peers & Incentives & Peer effects on performance \\
\hline $\begin{array}{l}\text { Bellemare, Lepage, } \\
\text { Shearer (2010) }\end{array}$ & $\begin{array}{l}\text { Data entry task } \\
\text { Canada - } 160\end{array}$ & $\begin{array}{l}\text { No / Private info on peers' } \\
\text { productivity. } \\
\text { communication }\end{array}$ & $\begin{array}{l}\text { Piece rate / Flat } \\
\text { pay }\end{array}$ & $\begin{array}{l}\text { (-) peer effects of very high or very low levels of } \\
\text { peer pressure, especially for males under fixed } \\
\text { wage. Conformism }\end{array}$ \\
\hline $\begin{array}{l}\text { Beugnot, Fortin, } \\
\text { Lacroix, Villeval } \\
(2019)\end{array}$ & $\begin{array}{l}\text { Arithmetic task } \\
\text { France - } 375\end{array}$ & $\begin{array}{l}\text { No Info / One-way / two-way } \\
\text { communication in networks }\end{array}$ & Piece rate & $\begin{array}{l}(+) \text { for males and females in unidirectional } \\
\text { networks; }(+) \text { for males and (no) for females in } \\
\text { bidirectional networks. Competitive rivalry }\end{array}$ \\
\hline Falk, Ichino (2006) & $\begin{array}{l}\text { Staffing envelopes } \\
\text { Switzerland - } 24\end{array}$ & $\begin{array}{l}\text { Single / Pair working in the } \\
\text { same room } \\
\text { No productive externalities }\end{array}$ & Flat pay & $\begin{array}{l}(+) 1.4 \% \text { for a } 10 \% \text { increase in co-worker's } \\
\text { productivity. Within-pair SD }<\text { between-pair SD. } \\
\text { Stronger effect on less able. Conformity }\end{array}$ \\
\hline $\begin{array}{l}\text { Georganas, Tonin, } \\
\text { Vlassopoulos(2015) }\end{array}$ & $\begin{array}{l}\text { Slider task in } \\
\text { teams of } 3 \\
\text { UK }-179\end{array}$ & No / Observed / Observers & $\begin{array}{l}\text { Piece rate / Team- } \\
\text { based pay }\end{array}$ & $\begin{array}{l}\text { (no) overall. Being observed increases performance } \\
\text { under team-pay only at the beginning. Observing } \\
\text { has an effect only under piece rate }\end{array}$ \\
\hline $\begin{array}{l}\text { Mohnen, Pokorny, } \\
\text { Sliwka (2008) }\end{array}$ & $\begin{array}{l}\text { Counting task in } \\
\text { teams of } 2 \\
\text { Germany - } 208\end{array}$ & $\begin{array}{l}\text { Final / Interim observability } \\
\text { of team members' effort }\end{array}$ & $\begin{array}{l}\text { Linear piece rate } \\
\text { applied to team } \\
\text { output }\end{array}$ & $\begin{array}{l}(+) \text { Peer pressure within teams due to inequity } \\
\text { aversion reduces free riding. Asymmetric: stronger } \\
\text { effect for those who perform more than teammate }\end{array}$ \\
\hline $\begin{array}{l}\text { Rosaz, Slonim, } \\
\text { Villeval (2016) }\end{array}$ & $\begin{array}{l}\text { Arithmetic task } \\
\text { France - } 104\end{array}$ & $\begin{array}{l}\text { Single / Pairs. Peer's } \\
\text { outcome observable / not. No } \\
\text { productive externalities }\end{array}$ & Piece rate & $\begin{array}{l}\text { (no) but peer effects cause workers to quit at more } \\
\text { similar times. Sociability effect more than social } \\
\text { comparisons }\end{array}$ \\
\hline
\end{tabular}




\begin{tabular}{|l|l|l|l|l|}
\hline Sausgruber (2009) & $\begin{array}{l}\text { Public good game } \\
\text { in groups of 4 } \\
\text { Austria - 196 }\end{array}$ & $\begin{array}{l}\text { Feedback on own and other } \\
\text { team's total contribution. No } \\
\text { externalities across teams }\end{array}$ & Team-based pay & $\begin{array}{l}\text { (no) Correlation between the effort of the other } \\
\text { team and one's team effort but no aggregate effect } \\
\text { on efficiency }\end{array}$ \\
\hline $\begin{array}{l}\text { Thöni, Gächter } \\
(2015)\end{array}$ & $\begin{array}{l}\text { 3-player gift- } \\
\text { exchange game } \\
\text { Switzerland - 489 }\end{array}$ & $\begin{array}{l}\text { No/Information on the other } \\
\text { agent's effort followed by } \\
\text { revision of effort }\end{array}$ & $\begin{array}{l}\text { Flat pay chosen } \\
\text { by the principal }\end{array}$ & $\begin{array}{l}(-) \text { Effort revised downward after observing that } \\
\text { peer's effort is lower, but not upward if peer's effort } \\
\text { higher. Conformity, social norm }\end{array}$ \\
\hline $\begin{array}{l}\text { van Veldhuizen, } \\
\text { Oosterbeek, } \\
\text { Sonnemans (2018) }\end{array}$ & $\begin{array}{l}\text { Arithmetic task in } \\
\text { groups of 4 } \\
\text { Holland - 188 }\end{array}$ & $\begin{array}{l}\text { No peers / Ability of peers / } \\
\text { Performance of a peer. One- } \\
\text { way communication. Effort } \\
\text { complementarity }\end{array}$ & Flat pay & $\begin{array}{l}\text { (no) effect of being observed on low performers. } \\
\text { Heterogeneity of reactions to observing high } \\
\text { performers: both free riding (-) and imitation }(+)\end{array}$ \\
\hline
\end{tabular}

Notes: Numbers correspond to the number of participants. SD for standard deviation 
